Portland State University

PDXScholar

2-14-1996

\title{
The Japanese Approach to the End of the Pacific War
}

Atsuo Hirano

Portland State University

Follow this and additional works at: https://pdxscholar.library.pdx.edu/open_access_etds

Part of the History Commons

Let us know how access to this document benefits you.

\section{Recommended Citation}

Hirano, Atsuo, "The Japanese Approach to the End of the Pacific War" (1996). Dissertations and Theses. Paper 5300.

https://doi.org/10.15760/etd.7172

This Thesis is brought to you for free and open access. It has been accepted for inclusion in Dissertations and Theses by an authorized administrator of PDXScholar. Please contact us if we can make this document more accessible: pdxscholar@pdx.edu. 


\section{THESIS APPROVAL}

The abstract and thesis of Atsuo Hirano for the Master of Arts in History were presented February 14, 1996, and accepted by the thesis committee and the department.

COMMITTEE APPROVALS:

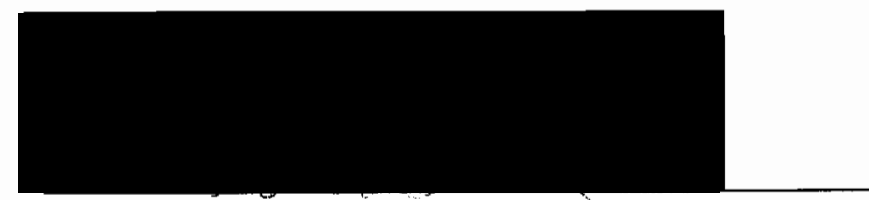

$$
\text { Bernard V. Burke, Chair }
$$

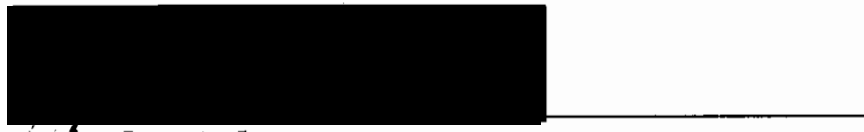

Linda Walton

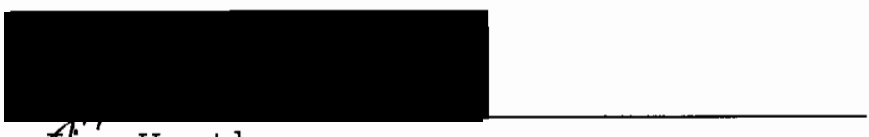

DEPARTMENT APPROVAL :

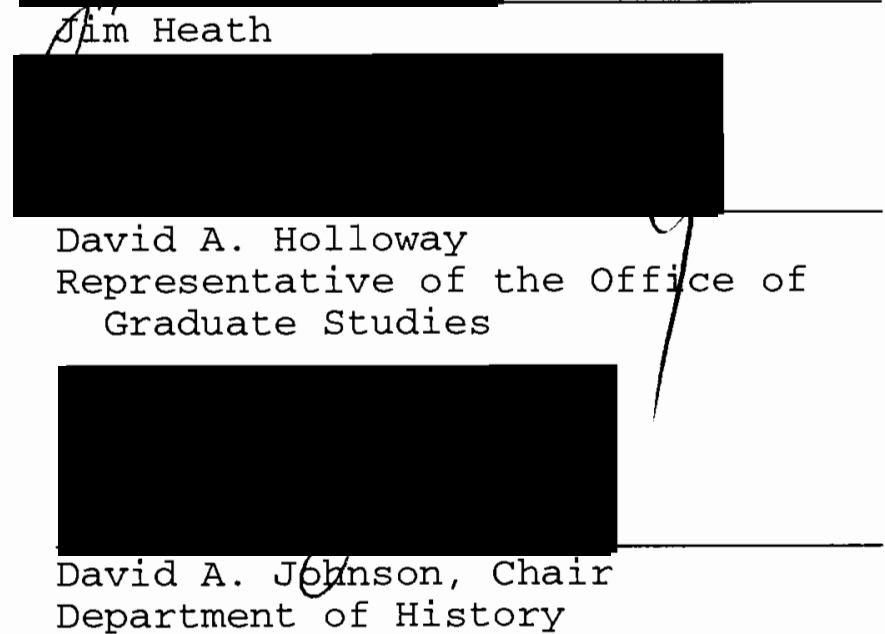

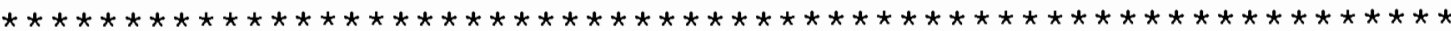

ACCEPTED FOR PORTLAND STATE UNIVERSITY BY THE LIBRARY

by

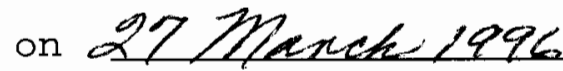




\section{ABSTRACT}

An abstract of the thesis of Atsuo Hirano for the Master of Arts in History presented February 14, 1996.

Title: The Japanese Approach to the End of the Pacific War.

Before World War II ended with the Japanese surrender to the Allied Nations on August 15, 1945, the United States dropped the atomic bomb on a Japanese city of Hiroshima. For fifty years, the question of whether the atomic bomb was necessary to end the war has been discussed by historians and journalists.

The purpose of this thesis is to clarify the Japanese situation in the spring and summer of 1945 by reading the statements and ideas of the Japanese Emperor, government officials and military officers at the time.

Since the Japanese Emperor was believed to have played a significant role in ending the war, it is necessary to examine his power and the nature of his decision making. Also, the Japanese Army still wielded significant 
influence on the Japanese government, it is indispensable to examine what the Army men thought and said at the time.

In the final stage of the war, the Japanese leadership came to realize that the retention of the Imperial system would be the only demand from the Allied Nations they could insist on. The American leadership knew this circumstance in Japan, and thought that the war could be ended by giving the Japanese the assurance of retaining the Emperor.

After the May 8th German surrender, the Japanese feared the Soviet entry into the war against Japan. They knew that Japan could not fight against all the world. Also, the Japanese feared the spread of communism through Soviet advance toward Japan. So the Japanese asked for the Soviet maintenance of neutrality and mediation in the war. Even when the Japanese were asking for the Soviet mediation, they had the alternative plan of asking for the direct negotiation with the United States in case the Soviet route was to be closed.

Through considering all these factors, it is concluded that in the summer of 1945 the Japanese were unable to continue the war and were seeking a way to end the war. 
THE JAPANESE APPROACH TO THE END

OF THE PACIFIC WAR

$$
\text { by }
$$

ATSUO HIRANO

A thesis submitted in partial fulfillment of the requirements for the degree of

\section{MASTER OF ARTS \\ in \\ HISTORY}

Portland State University

1996 
TABLE OF CONTENTS

INTRODUCTION

1

I THE EMPEROR CONTINUED THE WAR 5

II THE CRITICAL SITUATION IN JAPAN 36

III JAPANESE CONCERN ABOUT THE SOVIET ENTRY INTO THE JAPANESE WAR

IV DEALING WITH THE JAPANESE ARMY

V APPROACHING THE END OF THE WAR

CONCLUSION

127

BIBLIOGRAPHY 


\section{INTRODUCTION}

From the autumn of 1994 to the spring of 1995, the exhibition of the historical artifacts of the atomic bombing of Hiroshima at the Smithonian Institute in Washington D.C. became controversial in America. Among the several points in the dispute, the opponents of the exhibition pointed out that the original guidebook favored the Japanese side too much in the explanation of the Japanese war situation, depicting the Japanese as victims and the Americans as attackers. On the whole, the argument of each side did not necessarily clarify the Japanese situation at that time.

Also, in the summer of 1995, around the time of the 50th anniversary of the Hiroshima bombing, major American TV networks broadcast documentary and discussion programs concerning the atomic bombing on Hiroshima and Nagasaki. It opened a wide debate on the question of whether or not the atomic bombing was necessary to end the war with Japan. During the debates, the participants in the programs voiced rather stereotyped views of the Japanese in the spring and 
summer of 1945 .

The purpose of my thesis is to clarify the Japanese situation before the end of World War II by looking at some Japanese sources to contribute to the discussion of whether or not the atomic bomb was necessary to end the war in the Pacific and Asia.

Since the Japanese Emperor was the central figure in the process of ending the war, it is necessary to clarify the background and nature of his involvement in the war, and to ask the question of why he continued the war. Until his death in 1989, the Emperor Hirohito was a mysterious person. Many Japanese and Americans called him like-a-God figure. It is necessary to get rid of this veil and study his real role in the war. Especially, it is crucial to see his relation to the Japanese Army. He did not necessarily have complete control of his Army before and during the war, and this factor contributed to his delayed decision to end the war.

In America, many people still believe that the atomic bomb ended the war. As factors for bringing the war to its end, three years and nine months of severe battles in the Pacific island were far more important. Also, in the summer 
of 1945, American air raids and naval blockade had already brought the Japanese war efforts to near bankruptcy. Social chaos from the starvation of people was imminent. Continuously engaging in the war was to become impossible due to the scarcity of materials.

When the Japanese were suffering from devastation and near starvation in the war with the United States and other Allied nations, and the war was in the final leg in early August of 1945, the soviet entry into the war was considered as a decisive blow to the Japanese. The Japanese Army had wanted to end the war by Soviet mediation without losing face and to end the war on favorable terms.

Observing the defeat in Okinawa and the surrender of Germany, more Japanese came to realize that the defeat of Japan was inevitable, and that the battle on the Japanese homeland would bring forth tremendous disaster and chaos to Japan and an end to the imperial system. Contrary to the ostentatious cry of the Army men for the battle on the homeland, very poor defense conditions began to be exposed to the Emperor, government officials, and to the people. Facing the realities of the war, the morale of the people, as well as of many soldiers, was deteriorating. 
In the American preparation for the Potsdam Conference, the article for the retention of the Emperor was deleted right before the Potsdam Declaration of July 26, 1945, by Secretary of State James Byrnes. As predicted by secretary of War stimson, the Japanese did not immediately accept it. After the atomic bombing and the soviet entry into the Japanese war, the assurance that the Emperor would be retained made the Japanese finally decide to surrender. For bringing the war to its end, not a single factor was decisive, but rather many persons and many events gradually changed the situation in the direction to the end of the war by interacting and influencing each other. 
CHAPTER I

THE EMPEROR CONTINUED THE WAR

\section{Emperor's War Responsibility}

The Japanese Emperor Hirohito, now called Showa Tenno, approved the Japanese entry into the Pacific War with the United States and Great Britain in November 1941. He directed the war actively, and encouraged his soldiers in the reckless war in the Pacific, and in Asia. The Japanese government and military authority told the soldiers that to die for the Emperor was an honorable thing. Actually, about three million of Japanese soldiers and civilians died in the war, and a far greater number of people in Asia and in the Pacific became the victims in the war. Considering the fact that the Japanese fought the war in the name of the Emperor and many people became victims because of this, the question of whether the Emperor was responsible for the war sounds strange. However, this question has been asked for fifty years since the war. As Herbert P. Bix points out in his article, "Hiroshima in History and Memory: Japan's 
Delayed Surrender: A Reinterpretation," the ambiguous explanation of the Emperor's role in the war was caused by his minister's strenuous efforts to make him immune to the accusation of responsibility for the war and the United States government's and General Douglas MacArthur's policy to use the Emperor for the smooth occupation of Japan. ${ }^{1}$

Actually, MacArthur reported to the Army Chief of Staff Eisenhower on January 25, 1946, that:

No specific and tangible evidence has been uncovered with regard to the emperor's exact activities which might connect him with the political decisions of the Japanese Empire during the last decade. ${ }^{2}$

MacArthur added to this statement that removal of the Emperor would create the need for "a minimum of a million troops ... for an indefinite number of years." ${ }^{3}$ These two statements of MacArthur's are somewhat contradictory. While he asserted the Emperor's innocence in the first statement,

'Herbert P. Bix, "The Showa Emperor's 'Monologue' and the Problem of War Responsibility," Journal of Japanese Studies, 18 (Summer 1992): 322-332; hereafter cited Bix, "Monologue."

${ }^{2}$ Foreign Relations of the United States, 1946, Volume 8 . The Far East (Washington: Government Printing Office, 1971), 396; cited in Bix, "Monologue," 332.

${ }^{3}$ Ibid. 
he approved the opinion of the people who accused the Emperor of his conduct in the war even though MacArthur opposed the removal of the Emperor from his position.

By clearly understanding Emperor Hirohito's role in the war, from the beginning to the end, we will also be able to understand how the war came to its termination. If it had been Hirohito who started the war and ended the war, there would be no doubt that he would have been able to stop the war much earlier. If he really had such power, the next question would be what made him continue the war even long after Japanese defeat became likely at Saipan where Japanese forces were annihilated by the United States armed forces.

\section{The start of the Pacific War}

On November 30,1941 , about a week before the Japanese attack on Pearl Harbor, Hirohito's younger brother, Prince Takamatsu, tried to persuade his brother to avoid the war, saying that Hirohito could do it before the Navy started the offensive movement on December 1 . Takamatsu added that he heard from the Navy staff office that the odds would be 5050, or 60-40 in favor of the Japanese side. Hirohito said 
that he was afraid that Japan might lose the war. Then Takamatsu asked, "Why don't you drop the decision to enter the war?" Hirohito answered, "The military and the government are now moving toward the war. I have to approve what they have already decided."4 In this statement of the Emperor's, he concealed an essential point. For important proposals and decisions, military leaders and government ministers had to consult with the Emperor beforehand. It was almost like their asking the Emperor's approval to the matters they proposed. The Emperor was able to direct the government's and military's policies by asking questions or making them reconsider their proposals. When he approved his ministers' proposals, he said "Yes," or "Good," and for the ones he did not like, he just ignored them with sheer silence. ${ }^{5}$ Tojo Hideki, Prime Minister from October 18, 1941

${ }^{4}$ Fujiwara Akira, Awaya Kentaro, Yoshida Yutaka, and Yamada Akira, Tettei-kensho, Showa Tenno "Dokuhakuroku" [Full Investigation of the Emperor's "Monologue"] (Tokyo: Otsuki-shoten, 1991), 67; hereafter cited Fujiwara, Tetteikensho. indicated.

All translations are by the author unless otherwise

${ }^{5}$ Fujiwara Akira, Yoshida Yutaka, Ito Satoru, Kunugi Toshihiro, Tenne no Showashi [Emperor's History of Showa period] (Tokyo: Shin-nihon-shuppansha, 1988), 42. 
to July 18, 1944, has been considered as bad as Hitler and Mussolini in World War II. On December 31, 1947, he testified to the Tokyo War Crimes Court that "Japanese subjects are not supposed to do anything that the Emperor does not like. It is more true with the high officials in the nation." American chief prosecutor Joseph Keenan was shocked when he heard this because this statement contradicted his scenario of the war criminal trial. He wanted Tojo to be most responsible for the war and denied any possibility of indicting the Emperor. Keenan advised the Emperor's ministers to pressure Tojo to modify his previous statement. Tojo then said to the court on January 6 next year that "Previously he talked about his emotion as a subject to the Emperor, not the Emperor's war responsibility."6 So Tojo was forced to assume responsibility for the war, and to sacrifice himself for the Emperor, and Tojo accepted it. In Tojo's statement quoted above, the words "supposed" and "the high officials" are meaningful and important indicating different types of men among the people of lower ranks who

'Yoshida Yutaka, Showa Tenno no Shusenshi [Showa Emperor's History of Ending the War] (Tokyo: Iwanami Shinsho, 1992), 114. 
might have acted quite differently from senior statesmen like Tojo.

We need to see how the Emperor got involved in the whirlwind of the war. The Emperor appeared very happy in the early part of 1942 when the Japanese armed forces succeeded in their invasions in the Pacific and southern Asian theaters. Kido Koichi, chief adviser to the Emperor, recorded in his diary that on March 9, 1942, the Emperor, with a happy and smiling face, told Kido that the Emperor was amazed and pleased at the very quick victories of his army and navy in the Pacific and Southern Asia." He mentioned to Kido after the fall of Singapore on February 15 that "Japanese operations are succeeding this way because we prepared very well this time studying and discussing war strategies and tactic." ${ }^{8}$ Kido added that even at this time of felicity, the Emperor did not forget to instruct kido to think about good timing for ending the war.

'Kido Koichi, Kido nikki [Kido diaries], March 9, 1945 (hereafter cited Kido), cited in Fujiwara, Tenno no Showashi, 85 .

${ }^{8}$ Kido, February 15, cited in Fujiwara, Tenno no Showashi, 85. 
Objective of the War

At this time the Emperor revealed his objective in this war saying that until the Japanese forces completely secured and controlled the resources in Southern Asia, the Japanese could not help but continue the war. ${ }^{9}$ Kinoshita Michio, attendant to the Emperor, heard him say on December 11 , 1945, that Japan began and lost the war because of oil.10 However simplified, this statement still conveys the Emperor's sense of justification and the inevitability of the war. Here the Emperor indicated that that the well publicized slogan "Co-prosperity of East Asia" was a veil to hide Japan's real purpose of the war.

\section{Emperor's and Militarists' View of the World}

To understand the close relation between the Emperor and the military, we need to see how the relation between them developed. Herbert Bix points out that the Emperor and Japanese militarists shared the same ideas about the world

${ }^{9} \mathrm{Kido}$, February 12, cited in Fujiwara, Tenno no Showashi, 85 .

${ }^{10} \mathrm{Kinoshita}$ Michio, Sokkin Nisshi [Court Attendant's Diaries] (Tokyo: Bungei Shunjusha, 1990), 72-73, in Bix, "Monologue", 325. 
after World War I. They complained that Japan did not enjoy equality in the world. The complaints they harbored were: the Great Powers' pressure on Japan to reduce its armaments after the Washington Naval Conference in 1922; the United States' rejection of Japanese immigration to California and the whites-only policy in Australia; the abrogation of the Anglo-Japanese alliance; the American obstruction of the Japanese expansion in China. ${ }^{11}$ Even though the Emperor did not want the war with the United States and Great Britain personally, his world view became the background of his later acquiescence to the military adventures in the $\mathrm{Pa}-$ cific.

Contrary to the discontent of the Emperor and the military, the Japanese people in general welcomed peace after World War I. In this Taisho period (1912-1925), the Imperial government's control over the people was loosened, and political parties developed. Emperor Taisho, Hirohito's father, was suffering from syphilis, and his physical and mental conditions deteriorated. One day he caused trouble at an important Imperial ritual, which denigrated the au-

${ }^{11}$ Kinoshita, Sokkin-nisshi, 211-12, cited in Bix, "Monologue," 335. 
thority of the Emperor by disappointing the people regarding the personality of the Emperor. When he was expected to read an Imperial rescript, he began to make a telescope from the paper for the Imperial rescript and enjoyed the view from it for a while. This story spread quite widely among people because what they had expected from the Emperor was quite different. So when Hirohito became the Emperor after his father's death, he wanted to restore the authority of the Emperor. For this task, he found the military leaders more reliable and helpful than the politicians of the political parties. Facing international and domestic difficulties, the Emperor thought that the military men stood up while the politicians were corrupt. ${ }^{12}$

The Emperor thought that the Japanese invasion in Manchuria was legitimate because Japan had a large population in a narrow land and Japan had been developing its power quite rapidly. So he gave ex post facto consent to the Japanese military's advance into Manchuria, which the Emperor considered as a rural area. ${ }^{13}$ However, he was aware

${ }^{12}$ Ibid.

${ }^{13}$ Fujiwara, Tettei-kensho, 31. 
that the advance of the Japanese armed forces into northern China would cause a clash with the United States and Great Britain. ${ }^{14}$ When he approved of the further southern advance of the Japanese Army troops into Shanghai and Vietnam, he was actually leading the nation into a collision course with the United States and Great Britain, and the Emperor Hirohito should have been aware of it.

\section{Emperor's strong Tie with the Military}

In the final year of the war, one of the reasons why it took so much time for the Emperor to depart from the Army's position that the Japanese should fight to the last in the Japanese homeland is that the Emperor was so intimately related to the military. It was the Emperor's military, and its mission was to protect the Imperial system and promote the well-being of the Japanese Empire. In the early Meiji period (1868-1912), the government designated three fundamental duties of the people: taxation, education, and conscription. In the nation building of modern Japan, all these three duties of the people were directed to the establishment of a strong army and navy. Here, conscription

\footnotetext{
${ }^{14}$ Ibid.
} 
meant not just recruiting soldiers, but dedication of the lives of soldiers to the Emperor if necessary, and education meant to create and train young men and women who would be willing to do that. The result of the education was superb. The military men came to proclaim that they would protect the Emperor and the Imperial system by dedicating their lives. In turn, the Emperor came to rely on the military men. In the 1920s and 1930s, the more critical the situation became, the more the Emperor depended on the strength of the military. The Emperor's sanctioning of patriotic actions of young, spirited officers provided in turn a hotbed for military adventurism, which later the Emperor himself had a hard time dealing with. His attendant, Kinoshita Michio, described this circumstance:
Because the military stood up under such circum- stance, shouldering the frustrations of the na- tion, it was extremely difficult to check the spirited young men who formed its core, even though they acted recklessly without regard to means. For their reckless behavior appeared to exhibit some common ground with the patriotic action of freeing the state from deadlock. ${ }^{15}$

The February 26 incident of 1936, an attempted coup d'état

${ }^{15}$ Kinoshita, Sokkin-nisshi, 211-12, cited in Bix, "Monologue," 335. 
by young Army officers, was the first such disturbance the Emperor had to deal with. On that day, they attacked important cabinet ministers and Imperial Palace ministers proclaiming that they would defeat the corrupt government officials who, they presumed, obstructed the Emperor's ruling of the nation. In those days, stringent poverty prevailed in rural areas from the economic depression, and many of the Army soldiers were from those agricultural areas. In the incident, the Treasury Minister Takahashi Korekiyo was killed, and Suzuki Kantaro, later Prime Minister at the end of the war, was seriously injured. Some Japanese historians assert that the Army officials of higher echelons who had intended to establish a strong military government conspired for the incident. The Emperor suppressed the incident by issuing a special Imperial order by mobilizing the major Army organization. However, the shadow of assassination and coup by the military continued to haunt the government and Court officials.

The central principle of the Imperial Army and Navy was that the lives of soldiers were expendable for the wellbeing of the Emperor and the Imperial system. According to 
Army leadership, one of the Japanese advantages in the fighting in the homeland was that Japan still maintained a large number of human resources to spend even after war materials and other resources became scarce. ${ }^{16}$ It was this expectation of the Emperor and Army men that dragged the war on so long.

\section{Ramikaze Suicide Attacks}

The extreme example of the dedication of the soldiers' lives to the Emperor was the Kamikaze Special Attack Force. The first Kamikaze attack took place on 25 October 1944, when five navy Zero Fighters, each carrying a 250 kilogram bomb, plunged into U.S. warships and transports off the coast of Leyte. Encouraged by the results, Vice Admiral Onishi Takijiro of the First Air Fleet hastily recruited new suicide forces. Army air force units soon followed suit. Until Japan's surrender in August 1945, and especially in the Battle of Okinawa, the Japanese employed more than 2,000 planes for suicide attacks. 2535 Navy men and 1884 Army men were killed in these assaults on American ships. Thirty-

${ }^{16}$ Tanemura Sako, Daihon-ei Kimitsu-nisshi [Secret Dairies of the General Staff office] August 11, 1944, (Tokyo: Fuyo-shobo, 1985), hereafter cited Tanemura. 
four American ships were sunk and 288 damaged by these suicide squads. ${ }^{17}$ The operation of these suicide attackers was conducted under the full acknowledgment of the Emperor. When he heard about the Kamikaze attacks at Leyte, he expressed an emotional gratitude towards the Kamikaze fighters: "Did they have to do to such extent? I admire their courage and dedication from my heart."18 The Emperor's appreciation of the suicide attack meant his authorization of this tactic in the ongoing war. He and his followers perceived that this way of suicidal offence was psychologically effective against the American forces. In the fall of 1944, the Emperor still held the belief that if the whole nation stood up in this spirit, it would be possible to gain a victory. On September 7, 1944, Hirohito announced at the opening ceremony of the 85th special session of the parliament: "The enemy offensive is getting severer and the situation more critical day by day. Now is the time to get vic-

${ }^{17}$ Fujiwara Akira, Awaya Kentaro, Yoshida Yutaka, Showa 20 Nen, 1945 [Showa 20th Year, 1945] (Tokyo: Shogakukan, 1995), 112 .

${ }^{18}$ Yamada Akira and Koketsu Atsushi, esosugita Seidan: Showa Tenno no Senso-shide to Senso-sekinin [Emperor's Delayed Decision: Emperor Showa's Direction of the War and His Responsibility] (Tokyo: Showa-shuppan, 1991), 370. 
tory by using all possible means."19 This is the period when the senior statesmen became more desperate about the war situation, and some of them began to voice an extreme idea of dedicating 100 million lives of the people to defend the national polity, that is, the Imperial rule by the Emperor. ${ }^{20}$ However, the idea of "one hundred million Kamikazes" ended up only as those leaders' wishful thought. Hunger, destruction of homes, and all other sufferings demoralized the people.

\section{Tojo and Emperor}

The Emperor's close relation with the Army leaders, especially with Prime Minister Tojo Hideki, led to the Emperor's involvement in the war. He detested former Prime Minister Konoe as a person of weak will. ${ }^{21}$ When Prince Takamatsu, Hirohito's younger brother, tried to persuade Hirohito not to rely on Tojo so much, the Emperor told his brother that he would not hear the advice of an irresponsi-

${ }^{19}$ Ibid. , 174 .

${ }^{20}$ Ibid. , 173.

${ }^{21}$ Fujiwara, Tettei-kensho, 24. 
ble court prince. Ironically, Konoe and Takamatsu were two of the most prominent people who saved the Emperor from his fatal decision to fight on in the homeland. On the other hand, the Emperor trusted Tojo significantly. Kido said that the Emperor preferred the Army leaders, especially Tojo, because they were willing to implement what the Emperor wanted. This feature was most remarkable in Tojo. ${ }^{22}$ Even when people began to criticize him in the middle of 1944 after the repeated defeats in the Pacific, the Emperor still kept him as Prime Minister. A reporter of Asahi Shinbun [newspaper] recorded a conversation between Kido and Tojo:

Kido: Military and domestic situations are not favorable for the nation. Have you ever considered resigning from the premiership?

Tojo: It is regrettable that people began to criticize the government. However, since the Emperor's trust in me is unfading, I should not resign. ${ }^{23}$

The Emperor's trust in Tojo lasted even after Tojo resigned from the premiership on July 18, 1944. It meant that the Emperor maintained the same perception and policy of the

${ }^{22}$ Kido, March 20, 1946, cited in Yamada, Ososugita Seidan, 127.

${ }^{23}$ Yamada, Ososugita Seidan, 128. 
war.

\section{Yonai and Emperor}

However, we should not overlook the Emperor's cautious use of check and balance in the military and the government. According to the Imperial Constitution, the Emperor was supreme commander of the military and supervisor of the government; even though he tilted heavily on the side of the Army, he still maintained some check and balance in the military and the government. He trusted Navy Admiral Yonai Mitsumasa greatly, a man who opposed the Tripartite Pact of 1940 and reluctantly participated in the military conflict with the United States. It was Yonai who confronted the Army position of continuing the war in the spring and summer of 1945 on the grounds that Japan had used up materials and food to fight on. During the war in Japan it was only Navy men who could restrain the Army's will to fight on. 
Emperor's Engagement in the war

Different from MacArthur's report to Eisenhower, the Emperor Hirohito was quite active in directing the war. In the way he was involved in the war, we see that the Emperor was not forced to acknowledge what the Army did, but he behaved literally as supreme commander for the Japanese Army and Navy, if not an excellent one.

\section{(1) Shanghai}

Earlier in 1937, when the war with China spread to Shanghai, while Prime Minister Konoe wanted to restrain the Japanese advance, the Emperor earnestly encouraged the reinforcement of troops from Japan to Shanghai. ${ }^{24}$ From the Emperor's earlier statement that sending Japanese troops to Manchuria was no problem, but invading northern China would cause troubles with Anglo-American forces, it is hard to deny his responsibility for the war both in China and in the Pacific. If Hirohito and Konoe together had tried to prevent further incursion of Japanese forces in China, it would have been possible to reverse the tide toward the war. Hirohito's everlasting pursuit of exploiting China for Ja-

${ }^{24}$ Fujiwara, Tettei-kensho, 32 . 
pan's prosperity was in the background of his attitude toward China.

\section{(2) Bataan}

In early 1942, the Japanese forces in the Philippines were attacking the United States' fortress at Bataan. Impatient at the slow progress of the campaign, with fewer forces required to do the task, Hirohito frequently pressed the General staff office to reinforce the troops and get the work done quickly.25

(3) Guadalcanal

Hirohito pointed out three times the problem of not using the air power more extensively at the battle of Guadalcanal (August 7, 1942-February 1, 1943). The next day after his third request, the Army sent the air planes to the field. ${ }^{26}$

(4) New Guinea

After the retreat of the Japanese armed forces from Guadalcanal, Hirohito suggested that just retreating would

$$
\begin{aligned}
& { }^{25} \text { Ibid. , } 70 . \\
& { }^{26} \text { Ibid. , } 71 .
\end{aligned}
$$


not be good, and the Japanese should open new fronts for offensive movements to engage American forces. Yamada Akira says that the Japanese campaign in New Guinea was at quite a standstill and contributed to the prolongation of the war. ${ }^{27}$ The Emperor's occasional messages of appreciation and encouragement led the Army to give more attention and effort to the campaign in New Guinea, yielding, in turn, neglect in other areas. ${ }^{28}$

(5) Naval Battles

After the annihilation of the Japanese troops $(2,500$ men) at Attu Islands on May 29, 1943, Hirohito demanded naval engagements with the American ships. Navy Chief of Staff Nagano Osami responded that the Navy would soon obliterate American naval forces. Since it did not come true, Hirohito scolded Nagano sternly. ${ }^{29}$

(6) Absolute Defense Parameters On September 30, 1943, the Imperial Conference decided

${ }^{27}$ Ibid.

${ }^{28}$ Ibid.

${ }^{29}$ Ibid. , 72 . 
to set up new defense parameters in the Pacific. The Emperor insisted on this occasion that "defense parameters" did not mean that Japanese would defend only, but that they had to attack the enemy whenever they found the opportunity. ${ }^{30}$

(7) Recapturing Saipan

After the Japanese defeat at Saipan (July 7, 1944), the Emperor asked the General staff office to make a plan for retaking the island. Even after Tojo told the Emperor that it would be impossible, the Emperor persistently asked it. ${ }^{31}$ This episode attests that the Emperor knew how important the island of Saipan was for Japan's defense. However, the story also indicates his recklessness regarding the situation, the relative military strength of his side and the enemy's, and the safety of his soldiers.

(8) Beating Americans at Leyte

The Battle of Leyte was fought on October 24, 1944 . For the advisability of this battle, there were vehement

${ }^{30}$ Ibid.

${ }^{31}$ Ibid. 
arguments among the generals. The Emperor's opinion prevailed. He said that after beating American forces at Leyte, Americans would be brought to peace negotiation. ${ }^{32}$

(9) Landing Japanese Troops on Okinawa

United States armed forces landed on Okinawa on April 1, 1945, and rapidly occupied large areas of the island. Hirohito was stunned, and suggested to Chief of Staff Umezu that since Okinawa was so important, if the number of Japanese troops was not enough, Umezu should decide to send reinforcements from the sea. Yamada says that the Emperor at this time ignored the situation at Okinawa: 1500 American ships including 40 carriers and 20 battleships were surrounding the island, and 1600 American planes were engaging in the air raid. Yamada also says that the Emperor was so impatient that he urged the Staff office to take more offensive tactics while the military leaders in Okinawa wanted to fight a protracted war hiding in mountains and caves. Yamada points out that the Emperor's confusing order was one of the causes of the high casualty rate in the Battle of

${ }^{32}$ Terasaki Hidenari, Showa Tenno Dokuhakuroku, [Showa Emperor's Monologue] (Tokyo: Bunshun-bunko, 1995), 118. 
Okinawa that officially ended on June $23 .{ }^{33}$

(10) Attack Yun-nan in China

After the collapse of Okinawa became clear, the Emperor suggested Yun-nan as a new battlefront to damage considerably the Americans and the British. Chief of Staff Umezu did not consent to the idea, saying that Japan could not supply materials to that area. ${ }^{34}$

\section{Emperor Wanted to Fight on}

These are only a few examples that testify to the Emperor's involvement in the operations of the war. It is remarkable that even after numerous defeats, the Emperor always demanded new battlefronts to fight. Probably he thought that it would demoralize the Japanese forces and give momentum to the enemy if the Japanese only retreated after defeat. The Emperor believed that the Japanese would win until early 1945. It was obvious to the eyes of the Emperor that the United States was materially far superior to Japan. Hirohito wished victory which was similar to that

\footnotetext{
${ }^{33}$ Yamada, Ososugita Seidan, 183.

${ }^{34}$ Terasaki, Dokuhakuroku, 114.
} 
in the Russo-Japanese war of 1904-1905, that is, by concentrating all available resources (material and human), the Emperor thought that Japanese could inflict enough damage to an important section of the enemy to open negotiations for peace. In reality, it was Japan that suffered far more in a war of attrition.

\section{Emperor and Military Matters}

After the war, Hirohito wrote a letter to his son, Prince Akihito, the present-day Emperor, telling him the causes of the Japan's defeat in the Pacific war:

The Japanese emphasized too much faith in "God's nation" and the spirit derived from it, and ignored the power of science. The Japanese underestimated the military strength of the United States and Great Britain. Japan lacked competent military leaders such as Oyama Iwao and Yamagata Aritomo, the generals Japan saw at the time of the Russo-Japanese War. Military men, without a grand view of the situation, just arrogantly advanced forward. ${ }^{35}$

Since Hirohito was quite free of any kind of criticism, it seems that he did not develop a habit of self-reflection. So, while he accused others a lot, he did not talk much about his mistakes in his direction of the war. It was

${ }^{35}$ Terasaki, Dokuhakuroku, 100. 
Hirohito who promulgated the spirit of "God's nation," and it was he who insisted on continuing the war and supervised military operations. It was unfortunate for the Japanese in those days that Japan did not have competent military leaders who could properly advise the Emperor in his involvement in the war.

What Made The Emperor Continue the War?

After the watershed of the war, that is, the defeat at Saipan, on July 7, 1944, the Emperor continued the war not because he wanted to acquire new territory, but because he wanted a victory from the Allied forces so that the Japanese could end the war on better terms. He feared that if Japan surrendered to the Allies, the Allies would force the Japanese to accept unconditional surrender terms and to abrogate the Imperial System. ${ }^{36}$ The well-being of the Imperial Family was the Emperor's, court people's, and government officials' primary concern.

Prince Higashikuni was very much concerned about the future of the Emperor and the Imperial system because he belonged to the Imperial Family. On January 18, 1945, he

${ }^{36}$ Terasaki, Dokuhakuroku, 141. 
recorded in his diary his view on an American radio broadcast concerning the United States postwar policy toward Japan. The interesting point is that he noticed that the American policy was modified to more generous terms:

According to the American radio broadcasting, we know that in America people in various sections are now discussing the postwar policy on Japan. Before, there were opinions that asserted the termination of Japan as a nation. Nowadays such extreme ideas have receded, and discussions are going on concerning what systems the Japanese nation can take. Today's announcement goes as follows: 1. Japan can exist as a democratic nation. 2. The Imperial System should be abolished. 3. Army, Navy, Air Forces should be dissolved. 4. Those who were responsible for the war, and the military cliques, should be punished. 5. Japan should abandon Taiwan, Korea, Manchuria, Ryukyu Islands, and the Pacific Trustee Islands. 6. The Allies deploy their forces at important points in the Japanese homeland. Reading this announcement, I think that we should not allow these things to happen. We have to strengthen our defense. As an Imperial Family member I should do my best to protect the Imperial Family. ${ }^{37}$

It seems that Higashikuni spoke here for the Emperor. Early in 1945, there was a belief among the Japanese that the United States would not allow the Imperial system to continue in Japan if Japan surrendered, and Higashikuni pointed

${ }^{37}$ Higashikuni Naruhiko, Higashikuni Nikki [Higashikuni Diaries] January 18, 1945. 
out that the American broadcast supplied the ground for Japanese determination to fight the war to the end. All these terms sounded so harsh to the ears of the Japanese that this kind of American broadcast just contributed to solidifying the Japanese determination to fight to the end.

\section{End of Japanese Military and Imperial System}

Four years later, on December 20, 1949, Kido, chief adviser to the Emperor, shared with an officer of the occupation forces his recollection of the Emperor in early $1945:$ :

The Emperor's idea was that he could not help continuing to fight the war because he was afraid that Japan would be disarmed upon surrendering to the Allies. He often told me that a nation without its military cannot survive as a nation. ${ }^{38}$

For Hirohito, a nation meant a national polity with the present Imperial Family at its center. From his experience he was fully aware that in modern Japan the Imperial System had been empowered and protected from internal and international threats by the strong military, and the Emperor stood at the highest point in the military according to the Imperial Constitution of 1889. During the war, the Imperial

${ }^{38} \mathrm{Fuj}$ iwara, Tenno no Showashi, 90. 
Family got further entangled with the war mainly by the Emperor's active involvement in it. At this stage of the war, the end of the Japanese military seemed to the Emperor to be the end of the Imperial system.

\section{Konoe and the Emperor}

During the war, Prince Takamatsu, Hirohito's younger brother, said that it was only Konoe, former Prime Minister, who could estimate the international, domestic, and military situation objectively. In February 1945, the Emperor summoned senior statesmen one by one to hear their advice. They were former prime ministers and chief court attendants. According to the Emperor's memoir, while other statesmen voiced ambiguous or optimistic views of the war, it was only Konoe who stated a pessimistic view concerning the ongoing war. On February 14, Konoe told the Emperor to terminate the war immediately. The Emperor responded to him saying that he had still to see the result of the coming military campaign at Okinawa, for the Navy and Army were ready for it with high morale. According to the Emperor's dictated memoir, it was Navy Chief of Staff Oikawa who promised the 
Emperor a very certain victory in okinawa. ${ }^{39}$ Hirohito said to Konoe that it would be better for the Japanese to ask peace after a significant military achievement in a battle. Konoe then said to Hirohito, "I wonder if such an occasion of victory will really visit you. If it comes, it should be early enough, not half a year, or a year later."40 Hirohito continued the war because he still believed Japan could win. This instance of Okinawa reveals that the Emperor's erroneous conviction was primarily based on misinformation given him by his military advisors.

At this time, the Emperor asked Konoe if the United States had the intention to abolish the Imperial system. Konoe answered that considering the opinions of former Ambassador to Japan Grew and some other American officials, Americans would not eliminate the Imperial system. The Emperor then said that he had some doubt about Army chief Umezu's statement that the United States would abolish the Imperial System of Japan. ${ }^{41}$ Even though the Emperor still

\footnotetext{
${ }^{39}$ Terasaki, Dokuhakuroku, 119.

${ }^{40}$ Ibid. , $102-3$
}

${ }^{41}$ Hosokawa Morisada, Hosokawa Nikki [Hosokawa Diaries] February 16, 1945 (Tokyo: Chuko-bunko, 1979). 
followed the military line of continuing the war, and rejected Konoe's advice, the Emperor still paid some respect to Konoe's opinion about ending the war. In February 1945, the Emperor came to the point where he wanted to know the United States' intention regarding the post-war status of the Japanese Emperor.

Iriye Akira, a historian specializing in United StatesJapanese diplomatic relations, points out the significance of this meeting between the Emperor and Konoe. Iriye says that it was Konoe who told the Emperor on this occasion that unless the Emperor swept away the fanatical elements of the Japanese Army, Japan could not approach the United States, Britain, and China about concluding the war. Konoe thought that it was the only way to save the Japanese domestic order. ${ }^{42}$ When the Emperor was still thinking about winning a victory by using the military, Konoe tried to persuade the Emperor into reconsidering his relationship with the Army elements who were promoting the continuation of the war. His opinion that the United States would not enter into

${ }^{42}$ Iriye Akira, Power and Culture: The Japanese-American War, 1941-1945 (Cambridge, Massachusetts and London, England: Harvard University Press, 1981), 236. 
negotiations with Japan for ending the war if the Japanese government did not detach itself from the Army pointed out the heart of the problem in the Japanese process of ending the war. Even though this position was not understood and adopted by the Japanese leadership as a whole until the final days of the war, the fact that Konoe clarified the center of the problem in the Japanese course of the war was significant. As long as the Japanese continued to be controlled by the Army, the Japanese could not end the war. As Konoe had already suggested to the Emperor in February, the Japanese were finally able to bring the war to an end in August 1945 by refusing to hear what the Army men commanded, that is, the retention of the Japanese military and the refusal to have Japan occupied by foreign troops. In the spring and summer of 1945, the Japanese leaders who intended to bring the war to its end found that how the nation's army treated became the most important issue. The Japanese Army's resistance to peace was motivated by its desire to save itself from dissolution. When the Imperial system and the national polity became endangered by the continuation of the war, the Emperor and the civilian government officials than resolutely dealing with the tough and stubborn military men. 
CHAPTER II

THE CRITICAL SITUATION IN JAPAN

In early summer of 1945, in addition to repeated defeats in the battles in the Pacific and South Asia and exhausting campaigns on the Chinese mainland, the Japanese were enduring severe air raids and serious food shortages. Quite contrary to the government statements on radio broadcasts and newspaper reports, the morale of the Japanese people was actually deteriorating. Some government officials and military men estimated that Japan would be unable to continue the war in the near future. Some of them were even concerned that if the war continued, the Japanese government would collapse by itself from hunger and revolts of the people.

\section{Soldiers' Remains}

A tremendous number of soldiers' remains from the $\mathrm{Pa}$ cific islands and the China mainland were returned to their homes. At the same time, the government was deceiving the people by saying that Japan had been winning the war, and the war would soon end in a total victory. On November 17, 1995, I interviewed a 60-year-old Japanese man in Hamamatsu, Japan. He said that he was an elementary school boy in the last year of the war. Since his father was a shinto priest, 
he often saw a great number of remains coming to his home for religious purification. Even though he was a small boy, he interpreted the announcements of the General staff office on the radio that Japan was winning as false because he thought that if it were true, he would not have seen so many remains sent to his home. In those years of the war, many bereaved families felt the misery of war, and prayed for the early termination of the war.

\section{Air Raids}

United States Air Force General Henry H. Arnold said that American conventional aerial bombing had sufficiently pounded Japanese cities before the use of the atomic bomb:

The surrender of Japan was not entirely the result of the two atomic bombs. We had hit some $60 \mathrm{Japa-}$ nese cities with our regular $\mathrm{H} . \mathrm{E}$. and incendiary bombs, and as a result of our raids, about 241,000 people had been killed, 313,000 wounded, and about $2,333,000$ homes destroyed. Our B-29's had destroyed most of the Japanese industries and, with the laying of mines which prevented the arrival of incoming cargoes of critical items, had made it impossible to carry on a large-scale war. We had destroyed 10,343 enemy airplanes, compared to the 29,900 destroyed in Europe. Accordingly, it always appeared to us that, atomic bomb or no atomic bomb, the Japanese were already on the verge of collapse. ${ }^{1}$

If we inspect the nature of Japanese houses and residential areas, and consider the very poor level of the Japanese air defense system, we will find that Japanese cities in the year of 1945 were far more vulnerable to aerial bombing than

${ }^{1}$ Henry H. Arnold, Global Mission, (Blue Ridge summit, PA: Tab Books, 1949), 598 . 
the cities in Germany. The Japanese housing made extensive damage inevitable. So Arnold did not necessarily exaggerate the fact to promote the interest of the United States Air Force.

In 1945, most of the Japanese houses were built mainly of wood, bamboo, plaster, and paper. They were very vulnerable to incendiary bombs. Also, Japanese streets were very narrow, especially in urban areas. Most of the houses in cities stood side by side separated only by inches. The ratio of the area of houses against the whole area of the region in the Japanese cities was from 40 to 50 per cent, while in American cities it was about 10 percent. $^{2}$ So in the Japanese cities, once a part of the region caught fire, it would have spread quite easily and rapidly.

American B-29s, which flew higher than 10,000 meters above the ground, were no match for the Japanese planes which were made light to fly fast, and significantly, lower than 8,500 meters high. Japanese planes were lightly armored for this purpose, as was the case with the Zerofighter planes. This was the reason why Japanese planes were very vulnerable to the American attacks in the air, as in the case of the Mariana Turkey Shoot of June 1944, in which American fighter planes easily shot down their Japanese counterparts. As for anti-aircraft guns, the

\footnotetext{
${ }^{2}$ Saotome Katsumoto, Tokyo Daikushu [Tokyo Great Air Raid], (Tokyo: Iwanami-shinsho, 1971), 180 .
} 
Japanese ones were capable of targeting objects only 5,000 to 6,000 meters high.

Also by the time of the start of the American air raids on Japanese cities, a huge number of Japanese planes and expert pilots were already killed in the battles on the Pacific islands. Above all, the Japanese military had not fully prepared for an anti-air defense. A man in Kokura city told a representative of American Strategic Bombing Survey that:

We were not defended from the Allied aerial bombings. This situation was the same all over Japan. The government leaders are responsible for the misery of the people from air raids. They forced us to engage in the war. However, they did not protect us from the aerial attacks. ${ }^{3}$

The sixty-year-old man I interviewed told me that during air raids American bombers freely bombed whatever targets they wanted and he saw no Japanese planes flying for defense. He thought at that time that this situation was not what the winning nation could provide for the people.

By the way, Japan was among the first nations that initiated air raids on the civilians in cities. For the first Japanese air raid on a city, on October 8, 1931, during the Manchurian incident, the Japanese Army planes bombed Chin-chou in Manchuria. From 1939 to 1941, the Japanese Army air forces bombarded Chong-chin, the

${ }^{3}$ Fujiwara Akira, Awaya Kentaro, Yoshida Yutaka, Yamada Akira, Showa 20 Nen, 1945, [Showa 20th Year, 1945] (Tokyo: Shogakukan, 1995), 83, hereafter cited Fujiwara, Showa 20. 
Nationalists' government capital, 195 times and caused about 12,000 casualties. ${ }^{4}$ So the Japanese military attacked overseas civilians and did not effectively protect Japanese civilians from the American air raids.

Not only the Japanese Army failed to defend the people from air raids, but also the Army destroyed Japanese citizens' houses for its own convenience. The government and the Army gave the order to smash houses which were located near the edges of factories, transport centers, and military bases so that these installations would not catch spreading fire. Altogether 614,000 housing units were cleared away, usually by members of nearby neighbor associations working with ropes and hand tools. One fifth of all the housing destroyed by the war was lost in this manner, sending more than 3.5 million city residents out to hunt new places to live. ${ }^{5}$ This data reveals the low esteem the Japanese government and military had for the life of the people during the war. The military installations were far more important for them.

After the war, British scientific historian P.M.S. Blackett compared the air defenses of Japan and Germany during world War II in the book titled Military and

${ }^{4}$ Fujiwara, Showa 20, 80 .

${ }^{5}$ Thomas R. H. Havens, Valley of Darkness: The Japanese People and World War II (New York: W.W. Norton \& Company Inc., 1978), 158. 
Political Consequences of Atomic Energy. He explained how easy it was for Americans to use atomic weapons in the Japanese air where the anti-air defense was almost nonexistent in the summer of 1945. On the other hand, the German industrial and technological levels of producing airplanes was much higher than their Japanese counterpart, and Germans had a superb anti-air defense system. ${ }^{6}$

\section{Air Raid on Tokyo}

The first major American air raid on Tokyo occurred on November 24, 1944, with eighty-eight B-29s bombing the Nakajima Airplane Manufacturing Company. For the first stage of the Tokyo bombing, only the military facilities and factories were targeted. However, from March 10, 1945, civilians' living quarters began to be bombed. From 0:07 to $2: 37 \mathrm{AM}$ on that morning, about 300 American bombers, that took off from the air fields on Mariana Islands, dropped 189,590 large and small incendiary bombs in the area of 40 square kilometers in Tokyo from the height of 1,500 to 3,000 meters above the ground, about three bombs within the area of one square meter. ${ }^{7}$ Saotome Katsumoto, the author of the book entitled The Tokyo Daikushu [The Tokyo Great Air Raid]

${ }^{5}$ P.M.S. Blackett, Military and Political Consequences of Atomic Energy [The title of the American publication: Eear, War, and the Bomb] (New York and Tront: Whittlesey House. McGraw-Hill Book Company, Inc., 1948), 10, 66, 134.

${ }^{7}$ Saotome, Tokyo Daikushu, 15. 
quotes from M. Amline's account of the Tokyo air raid:

The Air Force specialists chose targeting areas and estimated the expected number of deaths. As soon as the order was issued, hundreds of planes took off. Guiding planes dropped flare bombs first to illuminate the targeting areas. Merciless sorties of bombers arrived one after another, and incendiary bombs were dropped to destroy the industrial areas and surrounding residential areas completely. ${ }^{8}$

In about two and a half hours, within the area of 40 square kilometers, 250 thousand houses were burnt down, 85 thousand people died, 40 thousand were injured, and one million people lost their homes. ${ }^{9}$ The American tactics for this attack was to encircle one area with flame by the use of incendiary bombs containing napalm that caused fire very effectively. Then other kinds of incendiary bombs were dropped to cause fire inside the circle. The people inside the circle ran toward the center of the circle only to become a lump of charcoal. ${ }^{10}$ The way the bombing of Tokyo on March 10 was conducted is by no means accepted. However, it is amazing that the Japanese military and the government allowed this kind of disaster to happen. American crews in this bombing mission reported to their headquarters earlier in this attack that they did not see any Japanese countering planes, though they encountered marginal shots from

\footnotetext{
${ }^{8}$ Ibid., 178 .

${ }^{9}$ Ibid., 181 .

${ }^{10}$ Ibid. , 188 .
} 
antiaircraft guns. ${ }^{11}$ In the spring of 1945 , the Japanese government and Army were too much preoccupied with the coming Allied invasion of the Japanese homeland and did not devise any substantial measures to deal with the ongoing and immediate disasters inflicted by the American attacks from the air. While the military was crying for one hundred million suicides for the war in the homeland, the city dwellers were losing confidence in the prospect for victory. An Army officer's opinion, concerning the chaos among the people after the Tokyo air raid, reveals the gap between the situation of the people and the intention of the Army. Colonel Sato Hiroo, Army Quartermaster, said on March 26:

The attitudes of people today are deplorable. When they should do their best to prepare for the coming battle with the Allied forces on our homeland, they are just preoccupied with evacuating from Tokyo. Train coaches are filled with baggages for evacuation, and roads are crowded with evacuees. What a shame that people just think about their life. Government and military leaders do nothing with this problem. We, the Army and Navy, will just do our best to win a victory in the battle on homeland. ${ }^{12}$

This Army officer's statement represented the total lack of strategical thinking of the Japanese Army. As Blackett stated in his book, the aerial offense and defense were very important features of World War II, as preludes to landing operations, with its purpose of destruction of war facilities to destroy enemy war power, and destruction of

\footnotetext{
${ }^{11}$ Ibid. , 180 .

${ }^{12}$ Colonel Sato Hiroo's Statement, Takagi Memoir.
} 
cities to demoralize the population. ${ }^{13}$ without considering any measures to defend cities from aerial attacks, their crying for victory just revealed their irresponsibility in the operation of the war. People became more and more suspicious of the statement of the government and military that Japan was approaching its victory. According to the Strategical Bombing Survey, in June 1944, only 10 per cent of the people doubted Japanese ultimate victory. In the spring of 1945, the number increased to 50 per cent. For its motivation, 34 per cent of those who doubted said that they doubted because of air raids, and 28 per cent because of the destruction of military facilities and continuing defeats. ${ }^{14}$

Hosokawa Morisada, Konoe's son-in-law and secretary, depicted the anger of citizens in Tokyo in his diary:

Some Tokyo citizens who suffered the disaster from the air raid protested the Army officers who came to investigate the damage by a military car splashing mud along the road and wearing fine clothes: People shouted to the officers, "You, the Army, make us suffer this way."

People were tired of the war, and they knew that the Army was still insisting on continuing the war at the expense of life and property of citizens. The Army issued the order of compulsory evacuation at will. Hosokawa added a question to his diary: "Did any other Army exist in the Japanese history

\footnotetext{
${ }^{13}$ Blackett, Military and Political Conseguences of Atomic Energy, 69.

${ }^{14}$ Fujiwara, Showa 20, 82.
} 
that was so cruel as the present-day Japanese Army?" Hosokawa also recorded the suffering of people in Kyoto and Osaka areas from air raids. He said that every street was full of people who were evacuating and carrying things to the countryside, and everyone he met said that he or she hoped that the war would soon end. ${ }^{15}$

On May 25, there was another large air raid on Tokyo, which was less severe than the air raid in March. The Imperial house and Meiji Shrine, where the late Meiji Emperor was enshrined, was burnt by spreading fire. Watching the Imperial Palace burning and shedding tears, Prime Minister Suzuki bowed for a long time, and later issued a statement of apology to the Emperor: "We will apologize to the Emperor for the burning of the Imperial Palace by pledging that we will fight the war to the bitter end." War Minister Anami presented a request for his own resignation because he was unable to protect the Imperial House from the air raid disaster. The Emperor responded to Anami by saying that the Emperor would pardon him and asked him to do his best to assist the Emperor in the very critical time for the nation. ${ }^{16}$

${ }^{15}$ Ibid. , March 29.

${ }^{16}$ Tanaka Nobumasa, Dokyumento Showa Tenno (5) Haisen [Documented History of Showa Emperor] (Tokyo: Ryokufushuppan, 1988), 239. 


\section{Food Shortages}

In the summer of 1945, the Japanese people became more and more hungry from the shortages of food. Because of this dire food situation, some government and military officials estimated that Japan could not continue the war into autumn. Prince Higashikuni recorded on May 12 that a House of Representative, Hirano Rikizo, reported to him that then in May people were eating rice that was stored for use during August, so in August there would not be enough rice to distribute, and wheat production would decrease considerably, so the food situation would become more and more serious. ${ }^{17}$ Before 1945, in Japan industries and agriculture were quite labor intense, that is, human skill and a large amount of man power were indispensable in its industries and agriculture. After millions of men were drafted to military service, the labor situation greatly affected the agricultural production.

Fish is an important source of protein for the Japanese. It was put on ration during the war. For the adult man, it was $50 \mathrm{~g}$ a day in April 1941, 36.5g in 1942, 10.5g in January 1945, $0 \mathrm{~g}$ in August 1945. The ration of sugar was stopped in August $1944 .{ }^{18}$ This government record reveals how the food situation deteriorated as the war went

${ }^{17}$ Higashikuni, May 12, 1945.

${ }^{18}$ Showashi Kenkyukai, Showashi Jiten [Dictionary of Showa History] (Tokyo: Kodansha, 1984), 330. 
on.

With the scarcity of rice, any plants that were considered edible were eaten. On November 1, 1944, the government issued a special direction to all elementary schools in the nation that school children gather acorns for food. They were to be processed into flour in village factories. ${ }^{19}$ On June 14 , attendants and servants at the Imperial court ate a strange kind of flour that tasted bitter and did not satisfy them. The rumor that what they ate was acorn flour spread quickly. On that day the Emperor suffered from diarrhea not because of acorn flour but from fatigue. ${ }^{20}$

On June 8,1945 , Marquis Kido feared the effect of the food shortages on the social order:

So it has to be observed that most of these supplies [foodstuffs] will have to be lost, especially in small towns and villages all over the country, since their antiaircraft defense has hardly amounted to anything. If this is correct, the extreme shortage of provisions and food stuffs that will sweep the country in the latter part of this year and thereafter---in light of the approaching chilly season---will cause serious unrest among the people at large. And, in consequence, the situation will be beyond salvation ${ }^{21}$

Akinaga was Chief of the Plans Coordination Bureau. His

${ }^{19}$ This is the story I heard from my 81 -year-old mother in the summer of 1995 .

${ }^{20}$ Kojima Jo, Tenno [Emperor], (Tokyo: Bunshun-bunko, 1981): 226 .

${ }^{21} \mathrm{Kido}$, June 8 . 
report to the Supreme War Council on June 6, on the Japanese social and economic conditions staggered government and military leaders including the Emperor. Among the factors that indicated the Japanese dire situation, he pointed out the importance of the food problem. He reported that in certain areas of Japan, the possibility of starvation of people was looming. ${ }^{22}$ The participants in the conference also felt the immediate problem of food shortage, since they lived in Tokyo, where problems from air raids and food shortage was most severe.

Since 1944, it became usual for the citizens in the cities to go out quite often to buy food in the agricultural areas, often with the whole family participating. They exchanged their belongings for food. Including rice, some agricultural food items were on ration. So it was illegal to sell and purchase agricultural products such as rice. Prosecutors became so busy in dealing with this illegal conduct of people that at some point they predicted looming social chaos from food shortages in the near future. ${ }^{23}$ strict regulations of the life of people were the base of the Imperial system that enabled the nation to engage in war. However, as air raids became severer and food

${ }^{22}$ Robert Butow, Japan's Decision to Surrender, (Stanford, California, 1954), 94.

${ }^{23}$ Shiryo Nippon Gendaishi 13 [Sources of Modern Japanese History], (Tokyo: Otsukishoten, 1985), cited in Fujiwara, Showa 20 . 
shortages became more intense, the controlling of the people was becoming more difficult.

\section{Shortage of oil}

Oil shortages were not less serious than the food shortages for the continuation of the war. For Japan, the issue of securing oil had been important. This had been one of the causes of the war between Japan and the United states. Now the scarcity of oil would become one of the causes for Japan to cease the conflict. February 6, 1945, Higashikuni recorded:

The government is now in consternation after finding that from now on no oil will come from South-east Asia. For the substitution, the government has just recently started to produce artificial oil from potatoes. ${ }^{24}$

Higashikuni added that the Japanese Navy lost most of its power partly because of oil shortages. He did not point out the important cause of the oil shortages. Japan wanted oil from South East Asia, however the destruction of Japanese naval ships in the battles with the United States naval forces made it impossible to enable Japan to transport oil from the south. Also, U.S. submarines were intercepting and sinking most Japanese merchant ships by early 1945. For the source of new Japanese fuel, Navy Chief of Staff Oikawa said to Marquis Kido on April 5, that "As regards oil, we have enough stock for six months. And after that we will depend

\footnotetext{
${ }^{24}$ Higashikuni, February 6, 1945.
} 
on the pine root oil." On the same day kido heard a similar statement from Army Chief of Staff Umezu: "Though we are most concerned about oil supply, we still have enough stock to hold out for several months." 25 These chiefs of staff knew that without oil the conduct of war would be impossible. With the knowledge that Japan would not have oil in the near future, they still proclaimed that Japan should continue the war. Since the Navy leadership actually considered the battle of okinawa as the Navy's final battle, they almost used up the resources they had in okinawa. On June 22, on the day when the defeat in okinawa was reported, Navy Minister Yonai Mitsumasa began to assert that since Japan did not have sufficient materials to engage in the war, the Japanese military was no longer able to continue the war. He predicted that Japan would plunge into crisis around August. ${ }^{26}$

\section{Internal Crisis to the Emperor}

(1) Konoe was concerned about the Japanese domestic situation. In February 1945, the Emperor invited Former Prime Ministers and other senior statesmen to the court to hear their advice concerning the ways to overcome the

${ }^{25} \mathrm{Kido}$, April 5, 1945, in Kido Koichi The Diary of Marquis Kide, 1931-45 (Frederick, Maryland: University Publications of America, 1984).

${ }^{26}$ Sanematsu Jo, ed., Yonai Mitsumasa Oboegaki [Yonai Mitsumasa's Memoir], (Tokyo: Kojinsha, 1988), 142; hereafter Yonai, Memoir. 
looming national crisis. Among those advisors only Konoe advised early termination of the war, because he thought the chaos from the defeat after the Allied landing on the main islands of Japan would give communists good opportunities for social revolution.

Quite different from other statesmen, Konoe was courageous enough to advise the Emperor to rethink his relationship with the Japanese Army, especially the radical elements within it, for Konoe thought that they were in the core for the war policy of bringing to the fighting on the homeland. He said that he feared mainly the national renovationists in the military, because a majority of Japan's military men came from families below the middle class, so it was easy for them to fall prey to communist doctrine. They tended to sympathize with the poverty in the life of the people and a rising voice of labor. Also, in the military education, military men were inculcated with the importance of "national polity", and Konoe thought that communists would exploit this point by saying that "national polity" and "communism" were compatible.

Konoe was also concerned that the enmity of the people toward the United States and Britain increasing through the bitter war would make them give more attention toward the Soviet Union. He was fully aware of the Soviets' efforts "to establish Soviet regimes" in Eastern Europe and "to promote the creation of at least pro-Soviet governments 
throughout the rest of Europe". ${ }^{27}$ From Konoe's point of view, it was desirable for Japan to cease the war immediately and mitigate the suffering and anger of the people because in this way Japan could avoid social revolution. As Prince Takamatsu once pointed out, Konoe was the only person in Japan who was able to consider the process of the war in the context of the domestic political and economic conditions and the international environment. While other senior statesmen generally yielded to the Emperor's and military's rather optimistic war policies, Konoe saw the military situation, and domestic and international political conditions realistically. His primary concern was not necessarily mitigating the suffering of the people, but rather defending the Imperial system. Konoe's advice of February 1945 to the Emperor is important in that he proposed a radical change in the Imperial government's attitude toward the military and the ongoing war with regards to the possibility of social chaos.

(2) Kido was worried about social instability. Kido was the most important person in influencing the Emperor. He met the Emperor almost every day, and people stopped by Kido's office in the Palace after they met the Emperor. Konoe said once that to change the Emperor's idea about the war, he first had to persuade Kido.

\footnotetext{
${ }^{27}$ Robert Butow, Japan's Decision to Surrender (Stanford, California: Stanford University Press, 1954), 47.
} 
Kido regularly heard reports from the national intelligence office for domestic security to find if there were any moves against the Imperial House and the war efforts among the people. So his opinion about the attitude of the people toward the war and the Imperial throne was based on real facts. On April 5, when senior statesmen gathered for discussions on the selection of a new Prime Minister and the proceeding of the war, Kido reported to the conference:

When the mainland is about to turn into a battlefield, the internal situation is immensely deplorable. The nation has not necessarily been cooperating with the government's administrative policies but has been what we call "looking aside." Even considering things like foodstuffs, increased production, and peace and order, we must form a Cabinet worthy of the people's trust. I should also like to call your particular attention to the fact that antimilitarism has become rather conspicuous lately. ${ }^{28}$

Different from the government and military's slogan "One hundred million people are determined to fight to death," this report indicates that people were tired of the ongoing war, and some people even began to oppose the government war policies. It is clear that few people really wanted "one hundred million suicides' war", and the more the government forced the people to fight on, the more it alienated them from it. Undesirable results from the war, that is, a staggering number of soldiers' deaths from the fronts, the suffering of the people from air raids, and the situation of

\footnotetext{
${ }^{28}$ Kido, April 5, 1945.
} 
near starvation, were awakening the people from a long sleep of the forced bond between the Emperor and the people. Even though the people were inculcated since childhood that "To die for the Emperor and the nation is an honorable thing," they gradually became aware of the ridiculousness of this teaching, facing the evils of the war and recognizing that the Emperor was responsible for the continuation of the war. So, Kido was most concerned about the criticism against the Emperor from among the people. From the records of the office of internal security, we can see what complaints people at that time had:

If Japan were to lose the war, the Emperor would be responsible, not the people. Whether the United States or Stalin were to control Japan, we the people do not care (arrest).

The Emperor killed lots of sons of the people, but he appears to be insensitive about the sorrows of the people (arrest).

Roosevelt and Churchill travel around the world for the solution of the war. How about our Emperor. He is making poems with his lady attendants at the Palace. If the late Maiji Emperor had lived, he would have gone at least as far as Taiwan (complaining letter to the Imperial House). ${ }^{29}$

Under the Public Peace Maintenance Law of 1925, and the revised one of 1941, the people were strictly prohibited from criticizing the Emperor. So, even though the number of these cases was still very small, the fact that those who dared to criticize the Emperor appeared, and the quality of

${ }^{29}$ Fujiwara, Showa 20, 87. 
the criticism was getting more serious was important. Konoe also told Kido that he occasionally heard the remarks critical of the Throne. ${ }^{30}$ Kido and Konoe shared the same feeling that the Imperial system was threatened not only from outside but also within the nation.

(3) Army officer Tanemura was concerned about the antiwar sentiment. Not only civilian officials, like Kido and Konoe, but also Army officers, like Colonel Tanemura, were concerned about the antiwar sentiment among the people. He recorded that: "Anti-war, anti-military, and anti-government sentiments permeate among the intellectuals. This is a sign of a period near the end of war." This recognition of Army men that people wanted to get out of war worked as a demoralizing factor for them.

(4) Professor Nambara visited important people to ask for peace. Professor Nambara and his colleague, Professor Takagi, visited military officers' offices and the Imperial Palace several times and offered their advice concerning the termination of the war. The Emperor recorded in his memoir Nambara's advice regarding the way to end the war. Considering the fact that later the Emperor did what Nambara recommended and what Nambara advised was reflected on the Imperial Rescript for the termination of the war, his advice was considered to be quite influential. On June 8 , Nanbara visited Rear Admiral Takagi's office. Takagi was Navy

\footnotetext{
${ }^{30}$ Kido, July 12, 1945.
} 
Minister Yonai Mitsumasa's secretary, and under Yonai's command Takagi was studying the measures for the termination of the war since 1944. Nambara told him that:

If Japan plunged into the battle of "one hundred million suicides" on the Japanese homeland, people will get angry at the Emperor, for he allowed it to happen. Also, if the Allies found that the Emperor was not useful for avoiding bloodshed, they would give up using the Emperor for the purpose of pacifying the Japanese military men and people. These internal and external factors would eventually undermine the Imperial system. The Soviet Union would exploit such a Japanese situation for the opportunity to spread communism into Japan. I would rather recommend the Emperor to proclaim that he would save the people from the suffering of the war, and bring peace to the world. Only in this way, he would maintain the respect of the people toward him, and restore his credibility in the international community. Already the morale of the people was very rapidly deteriorating. ${ }^{31}$

Nambara stood between the people and the Emperor, and interpreted the mind of the people for the Emperor.

By the summer of 1945, already more than three million Japanese people died at the battle fields and homeland. This was already enough for the people. If the Emperor had forced the people to suffer more, the people would have lost faith in him and begun to rebel against him. The internal crisis for the Imperial system was as serious as the external crisis.

John $\mathrm{W}$. Dower indicates in his book entitled War Without Mercy that people, in America during the war were not aware of the crumbling Japanese situation. He says that

\footnotetext{
${ }^{31}$ Takagi, Memoir, 282.
} 
many Americans were surprised when the Japanese surrendered so soon after the atomic bombing. ${ }^{32}$ If the American people had known the fact that the Japanese people were suffering from the agonies of the war, and the Japanese leaders were considering an end to the war, they would not have thought that the atomic bombing alone ended the war.

${ }^{33}$ John W. Dower, War Without Mercy: Race and Power in the Pacific War (New York: Pantheon Books, 1986), 54. 
CHAPTER III

\section{JAPANESE CONCERN ABOUT THE SOVIET ENTRY INTO THE WAR WITH JAPAN}

Even though the May 8 th German defeat was anticipated by the Japanese leadership ever since the Allied landing on Normandy, when it happened, they realized that it made the Japanese war effort tremendously difficult. Army Colonel Tanemura wrote in his office diary on May 1st, "Even though we are not surprised at the news of the German defeat, however, the situation surrounding Japan has become very serious. Now we must fight against all the world." ${ }^{2}$ The biggest concern for the Japanese after the German defeat was whether the Soviet Union would remain neutral in the Pacific War. From May 11 to May 14, the supreme War Council met responding to the new international situation, and the first and foremost agenda for the meeting was Russian problems. The Japanese government and military leaders knew that the Japanese-Soviet Neutrality Treaty of 1941 was signed from expedient and advantageous reasons for each side. Once Russians completed the war in Europe, they had no need to remain neutral in the war between Japan and the Allies. The

\footnotetext{
${ }^{1}$ Tanemura, May 1, 1945.
} 
Japanese feared the Soviet entry into the war in East Asia so much that if it were to happen, they thought that the war would be over for the Japanese.

\section{Tojo's Fear of the Soviet Entry}

On July 18, 1944, when Tojo resigned from the premiership, Colonel Tanemura recorded Tojo's biggest concerns in the war:

The Japanese war situation would become critical in two possible circumstances: when the Japanese Navy and Army began to conflict with each other; and when the Soviets began to join the war against Japan. ${ }^{2}$

Tanemura explained that even though Tojo was thought by the people to be adictator, actually he was so subservient to Navy leaders that he could not interfere in Navy matters, and this was the cause of his fall from his post. In the same way Tojo had a fear that some day the Soviet Union would begin to attack Japan. Tojo was not the only person who feared a possible Russian attack in the north; other military and government leaders shared the same feeling. There were several reasons to explain the Japanese fear of the Soviets.

\section{Nomonhan Incident}

A Japanese Army division was nearly annihilated by Russian armed forces lead by General Georgi K. Zhukov in the battle fought along the Mongolian-Manchurian border from May

\footnotetext{
${ }^{2}$ Ibid., July 18, 1944
} 
to August 1939. In the battle, about 18,000 Japanese Army officers and soldiers died. ${ }^{3}$ The main cause of this disaster was that the Soviet Army was equipped with mechanized modern weapons. The soviet troops were totally different from the time of the Russo-Japanese War of 1904. The battle of Nomonhan left among Japanese military men a sense of inferiority toward the soviet Army. One of the Japanese officers commented that European nations that fought world War I developed arms and means of war during the war, while Japan was left alone keeping old weapons." This fighting over a border dispute did not develop into a war, but resulted in a neutrality treaty between the soviet Union and Japan in April 1941. At this time, Japan had a hard time in the war in China and had decided to advance to South-East Asia. The Soviets needed such a treaty, too, because World War II had started in Europe and they had to deal with the difficult situation there. Learning a lesson from this bitter experience, the Japanese military began to modernize its weapons, though time and resources were not enough for the Japanese to catch up with the level and pace of the Russian and American production of arms.

Also, the Japanese Army maintained the mind-set which

${ }^{3}$ Taniguchi Katsuhisa, Noro-kochi Dokudan-tettai: Nomonhan no Hiroku [Retreat without Order from Noro Highland: Secret Records about Nomonhan Incident] (Tokyo: Oshisha, 1986), 206.

${ }^{4}$ Ibid. 
had become the cause of the failure at Nomonhan all through the Pacific War. At Nomonhan, in late June 1939, the Japanese Army leaders in Manchuria ignored the words of caution from Colonel Doi, the military attaché in Moscow, about the imminent soviet offensive, on the ground that negative views must not be allowed to dampen the field army's ardent resolve to smash the Soviet-Mongolian forces once and for all. Alvin D. Coox, the author of the book entitled Nomonhan says that it was apparent that the Japanese army did not know and did not want to know about enemy capabilities. It tended to twist reality to fit its

preconceptions and could not or would not accept evidence to the contrary. ${ }^{5}$ In the Pacific War, the Army leaders irresponsibly continued to make the same mistake.

\section{Emperor's Concern about the Soviets}

On July 22, 1944, Koiso Kuniaki and Yonai Mitsumasa formed a cabinet after Tojo's resignation. When these two men visited the Emperor after the formation of the cabinet, the Emperor told these men that they should never provoke the Soviet Union so that Japan could concentrate on the war with the Allies. ${ }^{6}$ Considering the close relation between the Emperor and Tojo, it is likely that the Emperor shared

${ }^{5}$ Alvin D. Coox, Nomonhan: Japan Against Russia, 1939 (Stanford, California: Stanford University Press, 1985), 1,086 .

\footnotetext{
${ }^{6}$ Hosokawa, July 22, 1944.
} 
Tojo's opinion that if the Soviet Union were to enter the war against Japan, the continuation of the war would become very difficult, or impossible.

Why, at this time, did the Emperor and Tojo begin to express their concerns about possible soviet attacks on Japan? Already in the previous year, soviet armed forces defeated Germans in the Battle of stalingrad and were making great westward advances toward Berlin. In June 1944, western Allies succeeded in landing on Normandy, and they, too, were advancing toward Germany. The prospect of the German defeat in Europe was becoming clearer to everyone in Japan. In the Pacific theater, the Allies had already broken the Japanese absolute defense parameters, and in July, the United States armed forces defeated the Japanese forces on the island of Saipan. The Emperor wanted to avoid a two-front war that had sealed the fate of Germany.

\section{Southern Sakhalin and Manchuria to the Soviet Union}

Earlier, on April 29, 1944, Colonel Tanemura, the chief of the Bureau for the Direction of the war in the General staff office, proposed a policy for avoiding possible soviet entry into the war against Japan:

To avoid the war with the Soviet Union, Japan should be ready to concede everything that the Soviets would demand. For that purpose Japan could hand over to Russia these territories: Manchuria, Liaodong Peninsula, Southern Sakhalin, Taiwan, Ryukyu Islands, Northern Curil Islands, and Korea. For this purpose, Japan could return to the condition before the 1894 Sino-Japanese 
War. Then, we can rebuild our nation again from the beginning.

Tanemura was a leading planner in the Army for the battle in the homeland. He considered that the soviet neutrality was absolutely necessary for the Japanese fighting in the homeland. On september 15, 1944, Tanemura recorded that Foreign Minister Shigemitsu proposed to the Supreme War Council a great concession to the Soviet Union if it became obvious that the soviets would join the war against Japan. Shigemitsu considered that the Japanese should concede Manchuria and Southern Sakhalin to the Soviet Union in the worst case. Tanemura advocated the Foreign Ministry's proposal and commented that the critical war situation necessitated such discussion as to future Japanese concessions to the Soviet Union and possible peace negotiation with the Chiang Kai-shek government. ${ }^{8}$ These concerns about the future soviet attitude toward Japan indicated unreliability of the Neutrality Treaty of 1941 .

On september 18, only three days after this supreme war Council that deliberated the measures for dealing with the Soviet Union, the Soviet Union sent a message to the Japanese government refusing to receive a Japanese plenipotentiary. Tanemura commented in his diary that the

${ }^{7}$ Haisen no Kiroku, 347, cited in Nishijima Ariatsu, Genbaku wa Naze Otosaretaka [Why was the Atomic Bomb Dropped?] (Tokyo: Aoki-shoten, 1985), 183.

${ }^{8}$ Tanemura, september 15, 1944. 
Japanese had already lost their military power to back up this kind of diplomatic activity. ${ }^{9}$ Probably this is Tanemura's private opinion in the diary about the futility of diplomatic activity toward Moscow. He pointed out an important aspect of wartime diplomacy, especially when dealing with the Soviets. Actually, a proposal of sending a Japanese plenipotentiary to Moscow arose again the next year, and this diplomatic effort became one of the causes of the delay in the process of ending the war. This problem in dealing with the Soviets reveals Japanese weakness in coordinating military and diplomatic activities.

\section{Stalin'B Anti-Japan Speech}

On November 7, 1944, for the anniversary of the Russian Revolution, Stalin made a speech, calling Japan an aggressor nation in the ongoing war. Up to that day, stalin had never referred to Japan in his speeches presumably respecting the neutrality treaty. However, for the first time he talked about the problems of Japan in the war. This great change on the part of the Soviet Union surprised the Japanese in every field. Stalin said:

Aggressors always prepare better beforehand than the nations that are invaded. Reviewing the Japanese first attacks at Pearl Harbor, other Pacific islands, Hong Kong, and Singapore, the war in the Pacific was started by Japan. Japan, as an aggressor had prepared far better than such peace loving nations as the United States and Great

\footnotetext{
${ }^{9}$ Tanemura, September 18, 1944.
} 
Britain. ${ }^{10}$

Responding to this news, there were three opinions in the Japanese government: First, Prime Minister Koiso should make a responding statement. Second, Foreign Minister Shigemitsu should do so. Third, the government should ignore it. Then, Konoe's advice of no comment prevailed. ${ }^{11}$ It is not known why he advised this way. In retrospect, it might have been much wiser if the Japanese government had investigated stalin's real intention and the background of this speech.

The Japanese Army evaluated Stalin's speech quite realistically. Vice Army Chief of Staff Hata reported to the Supreme war Council his estimation of stalin's intention:

We have been concentrating on the war with the United States, and as a natural consequence, Manchuria is today very poorly defended against possible Russian attacks. Since Russia today finds no benefit in the Neutrality Treaty with Japan, it is no wonder even if Russia abrogates it. Generally, for dictators, treaty and war are two different things. We should not assume that the Neutrality Treaty will continuously assure us the security it has promised.

On November 15, just the day before Hata made this report to the council meeting, he had received news of an ominous event that occurred on this day at a Siberian railway station. Lieutenant Colonel Kaneko, who had left Tokyo with

\footnotetext{
${ }^{10}$ Tanemura, November 9, 1944.

${ }^{11}$ Higashikuni, November $16,1944$.

${ }^{12}$ Tanemura, November $16,1944$.
} 
a new code, was found dead there. Although his bag with the code was returned to the Japanese embassy, the code was probably copied by Russian intelligence officers. Men at the Army staff office in Tokyo were stunned at the news. Since Hata had long been stationed in the Soviet Union, he told his subordinates that:

According to the Russian way of dealing with other nations, this blatant affair is the sign of Russia's intention to sever diplomatic relations. I have observed that similar things occurred in the Baltic states before relations with the soviet Union worsened. ${ }^{13}$

From his experience in Russia, he was able to predict that stalin would abrogate the Neutrality Treaty. However, in these statements of Hata's, we do not find the measures by which the Japanese Army would respond to the possible Soviet attacks if they were ever to happen.

\section{Response to the Yalta Conference}

A summit meeting of three Allied nations was held at Yalta from 4 to 11, February 1945. In this conference, problems related to both Germany and Japan were discussed. However, the agreement by the United states and the soviet Union regarding Soviet entry into the war against Japan was kept secret. Because of the secrecy of this agreement, while the Japanese harbored anxiety about possible Russian attacks against them, they continued to try to ask the Soviets to keep the Neutrality Treaty. Colonel Tanemura

\footnotetext{
${ }^{13}$ Tanemura, November 15, 1944.
} 
recorded on February 9, that there was a radio broadcast which announced the news of the Yalta Conference of the three Allied leaders, Franklin D. Roosevelt, Churchill, and stalin. They talked about the occupation of Germany, the economic organization to secure world peace. Tanemura noticed there was nothing about Japan in this broadcast. The absence of the article concerning Japan puzzled the Japanese.

On April 5, the last day of the Koiso cabinet, notification was given by the Soviet Union that it would not be able to renew the Russo-Japanese Neutrality Treaty. Considering this matter and Stalin's speech in November which accused Japan of being an aggressor, Foreign Minister Togo was suspicious about the agenda in the meeting at Yalta. So he instructed Ambassador Sato to obtain an assurance from the Soviet Union concerning the Soviets' intentions toward Japan. Later Togo received a message from Sato telling him that on April 27, Molotov assured him that the attitude of the U.S.S.R. regarding maintenance of neutrality had not altered. ${ }^{14}$ Molotov told a lie to hide the Yalta agreement with the United states. His tactics of deception were effective for biding time for the preparation of their attack on the Japanese forces in Manchuria by

${ }^{14}$ Togo Shigenori The cause of Japan (New York: Simon and Schuster, 1956), 279, translated and edited from Jidaj no Ichimen (Tokyo, 1952) by Togo Fumihiko and Ben Bruce Blakeney. 
keeping Japanese politicians and military men unaware of real Russian intention.

On June 7, Rear Admiral Takagi received a telegram on the possible Russian entry into the war against Japan from a Military attaché in Switzerland. It said:

At the Yalta Conference, Stalin offered Roosevelt Russian entry into the war against Japan, and Roosevelt accepted it not from urgent necessity but for promoting the policy of cooperation with the Soviet Union. ${ }^{15}$

Takagi does not mention whether this message was communicated to the Foreign Ministry, and other government agencies. It seems that the government and the staff office did not pay worthy attention to this message from a Navy officer in a foreign land.

\section{Eastward Movement of the Red Army}

Contrary to Molotov's "assurance", the Japanese border guards were reporting a large concentration of soviet Armed forces in Siberia to the General staff office in early April. They observed that the soviet Army began to transport some divisions and a considerable number of planes and tanks eastward in Siberia. Tanemura recorded in the Staff Office diary on April 16, that it was then necessary to estimate the time of the soviet entry into the war against Japan and decide how the Japanese Army would

${ }^{15}$ Takagi, Sokichi, Takagi Kaigun Shosho Oboegaki [Rear Admiral Takagi's Memoir] June 7, 1945 (Tokyo: Mainichishinbunsha, 1979), 269; hereafter cited Takagi, Memoir. Takagi was a secretary to Navy Minister Yonai. 
respond. ${ }^{16}$ Lieutenant Colonel Asai Isamu, Army Attaché, left Moscow on April 27, traveled all along the Siberian Railway to Manchuria to investigate the transportation of Soviet Army men and arms. Vice Army Chief of Staff Hata received his message:

I observed 12 to 15 trains per day carrying men and arms of the Red Army to Eastern Siberia. People appear to be starting a war very soon. I can tell that today Russian entry into the war with Japan is unavoidable. ${ }^{17}$

On May 14, Colonel Matsutani, who was appointed secretary to Prime Minister Suzuki in April 1945, reported the size of the Soviet forces on the Manchurian border to Matsudaira, secretary of Marquis Kido:

In late June, the Soviets on Eastern Siberia will have approximately 2,000 planes and 2,000 tanks, and in July and August, additional planes and troops will arrive from Europe. We have no means to avoid catastrophe from Russian entry into the war. ${ }^{18}$

Matsudaira did not necessarily consider this situation pessimistically, but he thought that Russian threat could be used as an alarm to bring home to everyone the necessity to end the war.

\section{Army's Response to the Soviet Threat}

Tanemura recorded that on May 5, the Army staff office

${ }^{16}$ Tanemura, April 16, 1945 .

${ }^{17}$ Kanto-gun (2) [Kwantung Army], 324, cited in Tanaka, Dokyumento Showa Tenno, 208.

${ }^{18}$ Takagi, Memoir, 233. 
drafted a plan for defending Manchuria from possible Soviet invasion. He described a split of opinions in the Army:

Some insisted that we should defend against the Soviets by maintaining our forces along the Manchurian-Soviet border, even if chances of victory would be tenuous. Others insisted that since it was likely that we could not defend Manchuria from Russian invasion, we should retreat as far south as the Manchurian-Korean border and secure Korea, the important part of the Japanese Empire. Finally, both sides compromised and decided that we would concentrate our forces in the Southern Manchuria and engage in a great protracted war. Four divisions were to be transferred from China to Manchuria. Some teams of troops have already begun to move according to this policy. ${ }^{19}$

since this is a diary for the staff office, not for outside readers, Tanemura honestly recorded the attitude of the Army against the imminent Soviet invasion. The Japanese Army knew that in Manchuria they did not have enough strength to fight against the Soviets. The best parts of the armed forces had been already transferred to the Pacific. The Red Army that had just defeated Germany was turned this time toward the Japanese, and the momentum they had picked up in Europe was still lasting. It seems that by this time the Japanese Army did not have any prospect of victory in Manchuria .

\section{Prince Higashikuni}

In wartime Japan, it was not only military men who were worried about possible Soviet entry into the war with Japan.

${ }^{19}$ Tanemura, May 5, 1945. 
Prince Higashikuni, as a member of Imperial Family, feared Soviet advance in East Asia. He knew that communism is incompatible with the Imperial system, and that the soviet advance and occupation of Japan, if it were to happen, meant to the Japanese the end of the Imperial System. On February 12, 1945, Higashikuni fearfully described the soviet advance in Europe:

In the morning, Arimatsu, an officer of the General staff office came to me and said: Presently, the Soviet Army has advanced as far as about sixty miles east of Berlin. The German factories in Silesia were confiscated by the Russian forces without any destruction. The Germans are concentrating their forces in the east front and the Russians are sending reinforcements to the west. They have already established communist governments in Poland, Finland, and Bulgaria, and had infiltrated into France and Italy. The Soviet Union is now politically conquering the entire Europe. ${ }^{20}$

Higashikuni wrote this diary, worrying about the future of East Asia. Once the Soviets were to enter the war in East Asia, the same thing would happen there. The soviet Union was contiguous to Manchuria and Korea, so East Asia could be tomorrow's "East Europe." If the Soviets were to enter Japan, the Imperial Throne would be far more in jeopardy than in the case American forces were to occupy the Japanese homeland. By this time, some people in Japan, especially people in the Imperial Court were probably weighing the possibilities of Soviet and American landing on the Japanese homeland.

${ }^{20}$ Higashikuni, February 12, 1945. 


\section{Army's Response to Soviet Move}

On April 18, Tanemura recorded that in the Army Headquarters, Major General Nishimura walked around the Army office busily and coordinated the opinions of the Army concerning the measures for dealing with the Soviet move in East Asia. In this diary, Tanemura revealed that: In Nishimura's first draft of the Army's basic policy, there was an article, "Through the soviet mediation, we will end the war." Then, after deleting it, the final draft became "We will implement sweeping measures for dealing with the Soviet Union." Tanemura was not certain whether the intention of the Army leaders was maintaining the neutrality of the Soviet Union, or ending the war through the soviet mediation.

There was a background story to this hesitation on the part of the Army leaders. Two days before, on April 16, at the supreme War Council for discussing the basic war policy, Navy Minister Yonai rather abruptly asked, "Do we not mean by the basic war policy today bringing peace to the war?" The Army representatives only answered that the basic war policy included important questions. Since saving face was very important to them, they could not tell the Navy leaders that they were considering the termination of the war. The Army leader, General Umezu asked Prime Minister Suzuki to 
present a proposal regarding the soviet continued neutrality and cooperation in ending the war at the next meeting. ${ }^{21}$ It seems that Yonai tested the intention of the Army leader by such a question, and he understood that even though Umezu was contemplating the termination of the war, he was unable to publicly announce his opinion, presumably considering roaring opposition to the idea within the Army organization.

\section{Konoe's Response to the May 8 Event}

On May 9, the day after Germany surrendered, Konoe gave a message to Navy Minister Yonai telling him that he should consult with Prime Minister Suzuki and Marquis Kido over the immediate procedure for the termination of the war. In this message, Konoe said:

If we change our policy from war to peace after having Russian interference or after the occupation of Japan by the Red Army, it would be too late. Because in that case, Russians would force us to have a communist government. I am most afraid of this point: The Japanese society today with some chaos from the war provides

Russians with a good opportunity for communizing Japan. ${ }^{22}$

Konoe persistently voiced his opinion about the threat of communism over Japan in the confusion from the war. He was a politician who was able to integrate domestic and international political issues into his considerations. He had a strong sense that the central issue in Japan and in

${ }^{21}$ Tanemura, April 18, 1945.

${ }^{22}$ Takagi Sokichi, Shusen Oboegaki [Recollections of the Termination of the War] (Tokyo: Kobundo, 1948), 39. 
the world in those days was a threat from communism. Konoe's advice struck Yonai quite significantly because he later often talked about the social chaos from the war and the necessity to end the war as soon as possible. In 1917, when Yonai was Military Attaché in Moscow, he observed the Russian Revolution, so probably he had a good understanding of why, how, and when a social revolution would occur. He might have compared war-torn Russia in 1917 and Japan in the summer of 1945. Yonai's recognition of the need for the early termination of the war was important because as Navy Minister he could exert significant influence on the Army for the reorientation in the Army policy of continuing the war. So Konoe made a right political move toward ending the war in this new situation.

\section{Umezu's Inspection Tour in China}

On May 28, the General Staff office decided to concentrate Japanese armed forces in Northern and Central China. The Japanese primary concern in the Chinese continent shifted from the Chinese to the Russians. In the first week of June, Chief of Army Staff Umezu made an inspecting tour in Manchuria and Northern China and returned to Tokyo on June 9. He reported the defence conditions in Manchuria and Northern China to the Emperor. Umezu's report became one of several reasons the Emperor used in deciding to end the war. The Emperor's memoir describes his interview with Umezu: 
According to Umezu's report, all the Japanese armed forces in China today could be equal in strength to eight American divisions. He said that if ten American divisions land on China, they would easily defeat us there. He had never before talked like this without confidence. ${ }^{23}$

This is a mysterious document. The concern of the Japanese Army in China and Manchuria in those days was possible attacks from the north by the Soviet forces. The Emperor and Umezu might have discussed what the Emperor's memoir did not reveal. Umezu might have talked to the Emperor that substantial part of Army forces in Manchuria were withdrawn to the Pacific, thus the Japanese would not resist possible Soviet invasion. It is unlikely that Umezu went to Manchuria to inspect the defense against possible American invasion in this region. Furthermore, the Emperor certainly knew that the Soviets concentrated more than one million troops along the Manchurian border, which was more than ten American divisions.

\section{Yonai and the Army}

Navy Minister Yonai was carefully watching the change of the Army leaders, especially Chief of Staff Umezu and War Minister Anami, in their attitude toward the war and peace issue. On May 14, he said to his secretary Takagi that:

... even though they cautiously keep silent, they are very afraid of Russian moves against Japan. They want the Soviet Union to confirm and extend the Neutrality Treaty, and to play a role of

\footnotetext{
${ }^{23}$ Terasaki Dokuhakuroku, 137.
} 
mediation in the war. They are recently losing confidence in the war [in the Pacific and Asia], and they want to end the war. ${ }^{24}$

It seems that Yonai was referring to the battle in Okinawa when he talked about the confidence of the Army in the war. The Japanese Navy considered Okinawa as its final large battle, and used up most of its power there. As for the Army in Okinawa, on May 4, the Army engaged in a large scale counter offensive to recapture the bases American forces occupied, but it resulted in a miserable defeat. By this time the prospect of the battle in okinawa was bleak to the Army leaders, and they were losing their credibility as well as their strength. The severity of the battle with very high casualty rates both for military personnel and civilians might have led the Army officials to estimate the war situation more realistically than before. In addition to losing the war in Okinawa, the May 8th German defeat staggered them even though they pretended not to pay attention to the fall of their European ally, and since that day the news of increased transportation of Russian armed forces to Eastern Siberia was reaching the Army Headquarters every day. The plan of the Army for fighting with the American forces on the Japanese homeland had been considered possible as long as the soviets remained neutral. In the first place, the Japanese military was able to fight the Pacific war up to this day because the Soviets had been 
engaging a difficult war in Europe. The changing situation proved that the convenient treaty for both sides so far was becoming an empty promise. As a military leader, Yonai was able to see the factors which were undermining the Army's confidence beyond its ostentatious slogans.

\section{Togo and the Army}

Togo Shigenori, Foreign Minister when the Pacific War started in 1941, became Foreign Minister again on April 9, 1945, pledging to end the war. He knew that the Army's insistence on continuing the war was the largest obstacle to peace. However, he found a breakthrough to this problem. He said:

Early in my tenure of office the Vice-Chief of the Army General Staff, General Kawabe, called on me with some of his subordinates and, explaining in detail the concentration of the Red Army in Siberia, requested me to do all possible to prevent Russian participation in the war. The Vice-Chief of the Naval General staff, Admiral Ozawa, made a similar request, as did also the Army Chief of Staff, General Umezu. ${ }^{25}$

From this account, it is known that the Army had no other recourse than asking the Foreign Minister's help for avoiding the Russian entry into the war against Japan. It is hard to understand why the Army and the Navy thought that the Japanese Foreign Ministry possessed such power as to stop the war. Togo thought that this was a good opportunity to move for an early peace by making "use of the desires of

\footnotetext{
${ }^{25}$ Togo Shigenori, The Cause of Japan, 279.
} 
the military services." ${ }^{26}$ Togo's objective was that in the process of approaching the Soviets for the assurance of the Neutrality Treaty, the Japanese would also ask the Soviets to mediate the war between Japan and the Allies. However, Togo himself did not think that at this juncture of the war, a diplomatic means would influence the war situation greatly. On May 16, Togo confidentially told Rear Admiral Takagi that diplomacy with the Soviet Union had many unpredictable elements, and in the ratio of 7 or 8 out of 10, Russians would not give the Japanese a favorable response. ${ }^{27}$ Togo's idea was that even if the odds were not favorable for Japan, still trying to approach the Soviets for the termination of the war would become one-step progress toward peace because now the most stubborn Army was at the table for the discussion over the subject of ending the war.

\section{Yonai's Work on the Army}

To bring the Army leaders to the line of the procedure of ending the war, Navy Minister Yonai played a role. At the Supreme War Council from May 11 to 14 , though Umezu and Anami agreed to the proposal of asking the soviets strict abiding to the Neutrality Treaty, and procuring further Russian favor, for example the Japanese buying soviet

\footnotetext{
${ }^{26}$ Ibid. , 280

${ }^{27}$ Takagi, Memoir, May 16, 1945: 236.
} 
petroleum, they were reluctant to ask the Soviets' mediation on the ground that the time was too early to do that.

However, at the Imperial Conference of June 22, Yonai

proposed to start the request of Russians' mediation, considering the rapidly deteriorating Japanese domestic conditions as reported at the Imperial Conference of June 8 . The Emperor showed a significant interest and asked the opinions of the Army leaders, Umezu and Anami. They did not oppose, though Umezu said that the implementation of this plan would need an utmost caution. ${ }^{28}$ It seems that by this statement Umezu was implying the problems of the young officers in the Army who insisted on continuing the war. Since Yonai had known these circumstances in the Army, he utilized the authority of the Emperor with the cooperation of Kido and others in order to have the appearance that the Emperor urged the Army leaders to advance in the war ending process. ${ }^{29}$

\section{Anami's Wish}

When Colonel Matsutani traveled to Kyushu with War Minister Anami in late May to inspect the defense conditions there, Anami confidentially talked to Matsutani that he was thinking about an early end to the war. In that case, Anami

\footnotetext{
${ }^{28}$ Yonai, Memoir, 131 .

${ }^{29}$ Yonai, Memoir, 131.
} 
could not tolerate the Japanese accepting miserable terms. ${ }^{30}$ The Army leaders remembered the way the Russo-Japanese war ended in 1905. At that time, the American President, Theodore Roosevelt, accepted the request to become a mediator. This time, the Japanese wished that the Soviet Premier Stalin would mediate the war in the Pacific. Just as their operations in the war were not always based on a realistic estimation of the situation, the Army leaders, expectation of a diplomatic solution of the war was not very realistic, either.

Also, their expectation of the mediation by Russians was based on a misleading idea that the Soviet Union won the war in Europe because the Japanese abided by the Neutrality Treaty, and did not attack Russia during their war with Germany. ${ }^{31}$ This time, it's Russians' turn to reciprocate favors. This is rather a naive way of looking at the international relations in war time.

\section{Kase Had a Doubt}

Foreign Ministry official, Kase Toshikazu, gave a message to Matsudaira, secretary to Marquis Kido:

I have a doubt about asking Russians for mediation. This is like crossing a dangerous

\footnotetext{
${ }^{30}$ Matsutani Makoto, Daitoa-senso Shuketsu no Shinso [The True Story of Ending the Japanese War] (Tokyo, 1984), 147; hereafter cited Matsutani, True Story.

${ }^{31}$ Togo, The cause of Japan, 281.
} 
bridge. I think that theoretically the direct negotiation with the United States and Great Britain would be the best choice, but the Army would not allow it. So, I propose that as a trial we ask the Soviets first, and see how they respond. At the same time, we will prepare for the negotiation with the United States and Britain, and if the Russians do not respond favorably, then we will shift to the negotiation with the Americans and the British. ${ }^{32}$

Considering what Togo and Kase talked about in requesting Soviet mediation, it seems that this decision was rather dictated by the domestic military and political circumstances, that is, alternatives for the diplomatic solutions of the war was very much controlled by the Japanese Army's preference. Just as the illusory promise by the Japanese military of victory at Okinawa was broken by American military force, the wishful expectation of Russian help in the war was to be crushed by Russian military force.

\section{Choice of Soviet Mediation}

Then, why did the Japanese choose Soviet mediation? The Army leaders thought that in that way they could save the Japanese military organization from the possibility of dissolution, because they knew that the American leadership had been strongly proclaiming the punishment of the Japanese militarists. Generally, Japanese politicians acquiesced to the idea that they could expect better terms through the good offices of the Russian government than by direct negotiation with the United States and Great Britain. The

\footnotetext{
${ }^{32}$ Matsutani, True Story, 148.
} 
Emperor talked about the choice of the Soviet Union for mediation in his dictated memoir:

The reason we chose the Soviet Union for mediation was that we thought other nations were not strong enough to resist the United States' demand of imposing the unconditional surrender on Japan. On the other hand, the Soviet Union was a strong nation, and we thought that Japan and Russia had such a relationship as to enjoy the Neutrality Treaty. Since we did not trust the sincerity of the Soviet Union in dealing with other nations, we needed to proceed in this venture cautiously.

The Emperor was worried about the United States demand of unconditional surrender because he thought that it might include the abrogation of the Imperial system. So he wanted to resort to everything that would moderate these terms. When he said that the Soviet Union was a strong nation, it seems that he reflected his subordinates' expectation that the Japanese could exploit the increasing U.S. and U.S.S.R. confrontation, and the Soviets would need a neutral, strong, and friendly Japan.

The Emperor's words of doubt about the sincerity of Russians indicated his concern about the possibility of Russian attack and advance in Manchuria and China. Certainly he shared a fear of communism with such people as Kido, Konoe, and Higashikuni who were intimately concerned about the future of Imperial Family. Expectation, doubt, and fear were all mixed up in this Japanese venture of asking the Soviets' mediation. The Emperor continued to say

\footnotetext{
${ }^{33}$ Terasaki, Dokuhakuroku, 141.
} 
in his memoir:

As the first attempt to approach Russians, Former Prime Minister Hirota met Russian Ambassador to Tokyo, Jacob A. Malik, with a deal that if Russia exported petroleum, Japan would concede to Russia such territories as Manchuria and Southern Sakhalin. Since Malik did not give any favorable answer to Hirota, I and the Japanese government decided to send Konoe to Moscow. Konoe accepted this mission, saying that he would even risk his life in this task. The Russian government responded to this request of accepting the Japanese plenipotentiary by saying that it would decide after Stalin and Molotov returned from the Potsdam Conference. However, Stalin did not give any reply, only, after a while Russians gave us the declaration of war on Japan. In this circumstance, we had no other way than accepting the unconditional surrender. ${ }^{34}$

Dealing with the Soviets was a difficult task, filled with anxieties and suspicions. In the first place, the Japanese held a considerable suspicions about the soviet intentions and moves. The Emperor and the government officials had heard the Russian preparation for entering the war against Japan. Then, why did they continue to depend on the Russian favor in ending the war? The main reason was that the leaders of the Japanese Army thought that this was the only way to get out of the war with their honor maintained, and that at the same time the Russian mediation of the war would become the best assurance to avoid the Soviet entry into the war against Japan. Also, the Emperor found his own interest in this deal with Russians. Other goverment officials considered that even though, for the moment, they yielded to

\footnotetext{
${ }^{34}$ Terasaki, Dokuhakuroku, 141.
} 
the Army's demand of trying to procure Russian favor, this was an important approach to the termination of the war. When the Red Army invaded Manchuria, the Kwantung Army, the pride of the Japanese Army, crumbled before the soviet armed forces, and the Emperor had to yield to the Allies' demand of the unconditional surrender on the condition that the Imperial system would be intact. 
CHAPTER IV

DEALING WITH THE JAPANESE ARMY

By the summer of 1945, the Emperor and his chief advisors recognized that Japan did not have the strength to engage in a major battle with the Allied military forces on the homeland of Japan. Especially in early May by observing the destruction the Allied forces had inflicted on Germany and recognizing that the Japanese military had not been able to resist the United States armed forces in Okinawa, they thought that if the Allied forces were to land on the Japanese mainland, it would end up undermining the Japanese throne. The Japanese Army as a whole insisted on fighting to the last on the homeland, and imposed its plan on the government. Navy leaders Yonai and Takagi observed that generally Army leaders were losing confidence, but young Army officers maintained their posture to fight on, and they controlled the atmosphere of the Army, and also the government. Though the military power of the Army proved to be not sufficient to deal with the Allied armed forces, the power was strong enough to threaten and police the opponents of their war policy within the nation. 
For those who thought that fighting on the homeland was not advantageous for the nation, it became important to maneuver the Army men into their position. Approaching the Soviets was one of the ways they tried for this purpose. Above all, the use of the authority of the Emperor was considered by many the best and final way to bring the nation to the termination of the war. Then, a question arises: Why did the Emperor definitely change his policy on the war in June 1945? Until that time, he maintained a belief that the Japanese military would win some kind of victory, if not a total victory, and that it would be advantageous for the Japanese to achieve better terms. Then, he came to want to end the war, because after observing the results of the military campaigns in Okinawa, he came to realize that already it would be impossible for the Japanese military to reverse the tide of the war. Moreover the surrender of Germany brought him to the reality of the power of the Allied nations. So, at this stage, the Emperor began to approach Konoe's position that the continuation of the war would not bring forth better terms, but rather endanger the throne.

In early May, Kido reported to Konoe the change in the Emperor's attitude toward the military. Until that time the Emperor insisted on refusing the Allies' demands for punishing Japanese militarists and dissolving the Japanese 
military, because he thought that Japanese disarmament would encourage Soviet advances on Japan. Kido said to Konoe that it took a long time for Kido to "massage" the rigid Emperor's position of depending on the military's pledges. Even on this occasion of May, Kido was trying to persuade the Emperor saying that considering the international situation of that period, the weakened Japanese military of 3,000 or 5,000 troops was not enough for the defense. Consequently the Emperor would no longer adhere to the position of defending the Japanese military in the process of bringing the war to the end. ${ }^{1}$ Whether he wished or not, the Japanese Navy and Army were crumbling internally for their own reasons. In this communication between Kido and Konoe, Kido revealed that, probably from Konoe's influence, the Emperor and Kido were aware of the American demand for the Japanese disarmament, and that Kido had been trying to persuade the Emperor into his separation from the military as a means to facilitate the process of ending the war. Also, if the Emperor had thought that the Japanese military was necessary to defend Japan from Soviet incursion, and then gave up this idea, what alternatives for the defense of Japan from the Soviet threat did he and Kido have in their minds? Asking for the solid Soviet neutrality would be one 1945 .

${ }^{1}$ Takagi, Memoir, May 13, 1945: 228; Hosokawa, May 24, 
of the answers. Also, like Konoe, Kido was thinking of approaching the United States. However, before doing that Soviet neutrality had to be tested.

Even though there was a change in the Emperor's attitude toward the course of the war in May and June of 1945, why was he unable to end the war quickly? Besides the Soviet factor, we need to think about the relation between the Emperor and the Army men. The Emperor's advisors, especially Marquis Kido Koichi, considered the element of timing was important for such important Emperor's order to the nation. The memory of the attempted coup d'état in 1936 by young Army officers was still vivid in the minds of everyone. Colonel Matsutani Makoto wrote later that during the last weeks of the war the question of how to deal with the problems of the Japanese Army became more difficult and important than dealing with the Allied attacks..$^{2}$

\section{Fighting on the Homeland}

According to Tanemura's diary, the idea of fighting on the Japanese homeland emerged when the Army Staff Office decided to give up the land fighting at Leyte on December 19, 1944. Even though the Japanese Army still held out in

${ }^{2}$ Matsutani, True Story, 161 . 
the Philippines, the emphasis of the Japanese defense shifted from the Pacific islands to the Japanese homeland. As long as the Japanese were determined to continue to fight the war to the last, fighting on their homeland was inevitable.

Those in the Army who planned the fighting on the homeland explained the advantages of carrying the fighting home. Above all, enemy forces would have a much longer supply line in the Pacific Ocean. The Army planners overlooked the technological advance in the American air transportation. In addition the Japanese knew the terrain and climate of their home country; Japan still maintained plenty of human resources, and the morale of the people was expected to be heightened for the defense of their mother land. On June 6, 1945, Foreign Minister Togo Shigenori talked to Rear Admiral Takagi, criticizing these reasons the Army planners enumerated for their strategy. He mentioned that the Army did not take into its consideration prevalent destruction inflicted on the Japanese by the American air raids. Moreover, the morale of the people was deteriorating. The international situation for Japan became worse, and diplomatic solution of the war became harder. It is interesting that Togo, as a seasoned diplomat, see the war situation more realistically than the Army planners. Probably from the long tradition of the Japanese military, 
the Japanese Army men had a tendency to consider the military plan in terms of ground operation, and underestimated the element of superior American air power, which made a very long distance of the Pacific Ocean a much lesser problem. Also, it was possible that the Army men admitted in their heart their weakness of not being able to deal with the American air raids, but they did not do so, because admitting their weakness meant to them admitting defeat and losing face.

Takagi added the deteriorating situation in okinawa to Togo's opinion. ${ }^{3}$ In this conversation, Takagi reviewed the battle of Okinawa in relation to the planned battle in the mainland of Japan. If the Americans were to land on the homeland, the disasters in Okinawa would be repeated in much larger scale there. On May 16, Takagi had heard from Army Colonel Sato that the Japanese forces in Okinawa would fall in two weeks, and that the planned battle in the homeland would also become a very serious and difficult one. ${ }^{4}$ Here, Takagi indicates that there were some officers in the Army who were seriously concerned about continuing the war after the situation in Okinawa became critical. Since the Army plan for fighting on the homeland was already made early in

${ }^{3}$ Takagi, Memoir, 267.

${ }^{4}$ Ibid., 238 . 
1945, Colonel Sato did not say anything to oppose the Army decision, but it is likely that in his mind the idea of fighting on the homeland became more unrealistic after the battle of Okinawa. From the start, the Army plan of fighting on the homeland lacked substantial conditions that assured victory or safety of the people. The battle of Okinawa revealed to the Japanese what fighting on the homeland would look like and what consequences it might have.

Even before Okinawa, there were people who criticized the government's and the Army's plan to make the homeland a battlefield. Earlier, on March 7, 1945, Admiral Okada criticized Prime Minister Koiso's defense plan against the future American landing. He talked to Takagi:

Prime Minister Koiso says that if 10 American divisions were to land on the Japanese homeland, 20 Japanese divisions will deal with them. People are now laughing at his idea saying that he should know how the Allied forces landed on Normandy. Americans have air superiority, so they will destroy our supply and communication lines completely. Since we have many rivers, they will destroy the bridges to obstruct the concentration of troops. Even if we have 50 divisions of troops, where shall we find weapons to give them? Here and there, Koiso talks to people that we will win, so they doubt about his sanity of thinking. ... A remark of Army Chief of Staff that the battle in the Philippines will turn out to be our victory is perplexing to everyone. ${ }^{5}$

Prime Minister Koiso was an Army general, so his ideas

${ }^{5}$ Takagi, Memoir, March 7, 1945: 168. 
represented those of the Army. Okada, a Navy leader questioned the rationality of the Army plan of fighting with the American forces on the Japanese homeland. Already at this stage it was revealed to nearly everyone that the Japanese military was unable to defend the people in cities against the American air raids. In the Army plan, it seems that the Army planners interpreted "the landing of American forces on the Japanese homeland" as the landing of American soldiers on the Japanese land, overlooking the aid of American air power. Out of the 50 newly organized divisions, 25 divisions were to be deployed in the trenches along the coasts on the Pacific Ocean. Many of the soldiers in these trenches had bamboo spears, for only 700,000 rifles and only 23 percent of the required number of machine guns were available. Only a very small number of officers who were military school graduates were to train and direct these new soldiers. ${ }^{6}$ Just the number of troops, two million, was astounding, enough to overwhelm the American leadership in Washington, but the substance of the Japanese defense for the homeland was amazingly poor.

In the spring and summer of 1945, there were various kinds of episodes that exposed ridiculously poor conditions of the Japanese defense against the possible invasion of the

${ }^{6}$ Teikoku Rikugun no Saigo (3) [The End of the Imperial Army], 150, cited in Tanaka, Dokyumento Showa Tenno, 144 . 
homeland. The Governor of Kochi prefecture, Takahashi Saburo, talked to Marquis Kido:

In our area, newly recruited soldiers are trained with cannons which are made of wood from the scarcity of iron. If the people hear about this story, their morale will be weakened.'

Kido told this story to the Emperor. So probably this story together with other similar reports to him contributed to his reconsideration of the plan for fighting on the homeland.

Japanese Navy leaders were well aware of the anachronistic ideas of thinking of Japanese Army men who remembered the days of the Russo-Japanese War of 1904, when the spirited soldiers fought the land war with the Russian counterparts face to face on the fields of Manchuria. However rational the opinions of these Navy leaders were, they were not able to change the government plan of fighting on the homeland. The Army was still dominant having millions of soldiers, and the Emperor was still on the side of the Army plan at this stage. From the spring of 1945, such Navy men as Yonai and Takagi became more active politically to criticize the Army policy, to lead it to a more rational position, and together with Kido and Konoe to influence the Emperor to the direction of ending the war.

\footnotetext{
'Shoda Tatsuo, Jushin-tachi no Showashi [Showa History of Senior Statesmen] (Tokyo: Bunshun-bunko, 1984), 367.
} 


\section{Emperor and Defense Conditions}

There is an episode that indicates the change of the relationship between the Emperor and the Army leadership. On June 3, 1945, the Emperor sent most of his Military Aidede-camps to the beach called Kujukurihama [ninety-nine-mile beach], about 40 miles south-east of Tokyo, for the purpose of inspecting the defense conditions of this area. As the name indicates, this beach was very long, having a wide and flat hinterland. From the nature of the terrain and proximity to Tokyo, it was considered that the American forces would land on this area. After the inspection, these men reported to the Emperor that they were hardly able to find any substantial defense in this area. Since they went on the inspection tour not long after Army Chief of Staff Umezu reported to the Emperor on the satisfactory defense conditions of this area, the credibility of the Army Chief sank. ${ }^{8}$ Also, Umezu had made another report to the Emperor on the equipment of arms to the newly organized divisions for the defense of the homeland. Later the Emperor found from the other source that in actuality many soldiers had

${ }^{8}$ Daihonei Rikugunbu (10) [General Staff Office, Army Department] (Tokyo: Asagumo-shuppan-sha, 1975), 449. 
neither rifles nor bayonets. ${ }^{9}$ From these cases, the Emperor found that up to that day he had been informed of only nice things about the Army. His order to his aides for the inspection of defense conditions after Umezu's report meant that the Emperor had begun to doubt about Army leaders' account on the national defense. These episodes signify that throughout the war the information to the Emperor concerning the operation of the war had been altered by the military to promote the Army's and Navy's interests and objectives. The recognition of the Emperor that he had not been always truly informed of the war situation motivated him to reconsider the continuation of the war.

\section{Anami's Inspection Tour in Kyushu}

In late May, 1945, War Minister Anami traveled to Kyushu to inspect the defense conditions in that area. Kyushu is the southernmost island among the four main islands of Japan. The Japanese considered that if the Americans were to invade Japan, Kyushu would be the first target for their landing. Colonel Matsutani accompanied him in this tour. What is curious about this tour is that Anami was a person who persistently insisted on continuing the war until the day before the ending of the war. On the other

${ }^{9}$ Ibid. 
hand, Matsutani's position in the Army was that he was assigned to study about the time and measures for ending the war. After the tour, Matsutani informed Takagi that the War Minister felt in the tour that the defense of Kyushu against the possible invasion by American forces would be extremely difficult. ${ }^{10}$ At this time, Anami told Matsutani that he would like to end the war if the Japanese were to be offered favorable terms. ${ }^{11}$ The fact that Anami inspected the defense conditions of Kyushu in person, and had an impression that the Japanese defense of the homeland would become a difficult one is important. In the last days of the war, when young officers pleaded with him to pronounce his position of continuing the war by refusing to give a signature to the government document for ending the war, and by resigning from the cabinet post, he decided to join the side of peace, and after he was assured that the war would officially end, he committed suicide. In that difficult time of his decision, the inspection tour to Kyushu might have been one of the important factors for his decision.

\section{One Hundred Million Suicides War}

"Ichioku Gyokusai" is the original Japanese word for the term "one hundred million suicides war." The word

$$
\begin{aligned}
& { }^{10} \text { Takagi, Memoir, } 257 . \\
& { }^{11} \text { Matsutani, True Story, } 147 .
\end{aligned}
$$


"gyokusai" literally means "a glass ball flying very fast hits a rocky wall and splashes away in tiny particles." The phrase is used as a rhetorical and proverbial expression meaning "If a person is forcefully determined without any hesitation, and go his way on and on, he will do it." The advocates of the Imperial system utilized the phrase as a slogan to encourage the people to dedicate their lives for the protection of the Emperor. This idea was emphasized so much that in actual wars the literal meaning of the term took the place of its rhetorical use. Many deaths of soldiers in the Russo-Japanese War of 1905, and the invention of Kamikaze-attackers were the examples of the implementation of this idea.

In the spring and summer of 1945, those advocates of fighting on the homeland actually thought of imposing this idea of "one million suicides in the war" to protect the national polity, that is, the Imperial system. Lieutenant Colonel Ida Masataka used a legendary story in the history of Paraguay in South America when he tried to persuade Lieutenant General Mori Takeshi into coup d'état for establishing a military government to prosecute a defense war on the homeland:

In early 19th century, Paraguay fought a very harsh war, in which the President of the nation died in the battle, and the people died in the fighting until the population became a sixth of the original population. This is really an 
example of pride of a nation. ${ }^{12}$

For Ida and his colleagues, this story was not just a legend, but a scenario according to which the Japanese should fight the war to the end. For this kind of fanatical idea not only these radical young officers were responsible, but also many people in the government shared the idea of fighting to death. For example, Prime Minister suzuki Kantaro pronounced just before he became Prime Minister on April 5, 1945 that "... today, we must, of necessity continue the war at any cost," and he emphasized the necessity "to die in action for His Majesty. Japanese Imperial wars were performed on the foundation of this idea, expending the lives of soldiers and people for the Emperor up until August 15, 1945.

\section{Konoe's Opposition to Fighting on the Homeland}

Former Prime Minister Konoe Fumimaro persistently opposed the continuation of the war, especially the land war on the Japanese homeland, on the ground that the chaos in society from the war would become a hotbed for social revolution. On January 22,1945 , he said to Takagi:

If Americans were to land on the Japanese mainland and we were forced to engage in a guerilla

${ }^{12}$ Ito Takashi, Hata Ikuhiko, Hando Kazutoshi, "Shusen to Waheikosaku no Nazo ni Semaru [Approaching the Riddle of Ending the War and Peace Move]" Gendai [Modern Period], September, 1995 (Tokyo: Kodansha), 60 . 
warfare, it is the situation communists want to exploit very much. If we allow this kind of situation to happen, Japan will be in total chaos and the national polity would be in jeopardy. ${ }^{13}$

At this stage of the war, when most of the politicians supported or passively followed the Army plan of fighting on the homeland on the ground that only in that way people could protect the Emperor and the nation, Konoe argued quite differently. He asserted that far from defending the Emperor, fighting in the homeland would rather put the Emperor in a dangerous situation. The Japanese society during the war was tightly controlled and regulated by the government and the military, in other proper words, the people were suppressed and forced to fight the war. If the American armed forces were to land on Japan and some parts of the Japanese police and military powers were to stop functioning, Konoe did not think that, in that situation, all the people still show their allegiance to the military government. He had some sources of information which indicated that in the spring and summer of 1945, there were some people who did not hide their anger at the Emperor over their suffering from the war. ${ }^{14}$

Konoe was most concerned about the communists'

$$
\begin{aligned}
& { }^{13} \text { Takagi, Memoir, January 22: } 123 . \\
& { }^{14} \text { Kido Koichi, Diary of Marquis Kido, 1931-45, July 12, }
\end{aligned}
$$
(Frederick, Maryland: University Publications of America, 1984). 
influence on radical elements in the Army who insisted on the continuation of the war. On February 14, Konoe pointed out to the Emperor that since the majority of the Japanese professional military men "hail from families below the middle class, their whole environment of life has been such that it is easy for them to fall prey to Communist doctrine." So Konoe asserted that the earlier termination of the war would be more favorable, and for this purpose, the elimination of these radical elements in the Army was necessary ${ }^{15}$

In spite of these concerns, in February 1945, Konoe's advice did not change the Emperor's idea about the continuation of the war. However, it is not right to say that the Emperor ignored or did not understand what Konoe said. At this time, the Emperor said that he had to still see the result of the battle of Okinawa, for the Army and Navy were willing to fight the battle. He wanted to have a victory before his government went to negotiation with the United States because he thought that it would assure him better terms for Japan. At the same time, this statement signifies that when the military had already begun to move for the preparation of the battle, it would be hard for the Emperor to stop the move. It seems that there was a gap in

${ }^{15}$ Butow, Japan's Decision to Surrender, 48. 
understanding the power of the Emperor in relation to the Army between the Emperor and Konoe. Konoe understood that the Emperor had the absolute power over the Army, and he should wield the power to change the course of the war. The Emperor thought that though it was supposed that he commanded the Army, it was not always so easy for him to do that. As Konoe talked to the Emperor, certainly the Emperor had power which no other person in Japan had. The problem was that the Emperor did not use the power to compel the Army to move in the direction the Emperor wished. Harada Kumao was a secretary to Saionji Kinmochi, one of the most influential politicians in modern Japanese history, and a long-time advisor to this Emperor. Harada was an intimate friend of Konoe. Later Konoe talked to Harada about this February 14th interview with the Emperor:

I talked to the Emperor about my opinion of the Army. He told me that he also thought that something must be done with the problems of the Army, and asked me what he could do to solve the problems. I answered that since he knew best in the nation about the affairs of the Army, he could change the behavior of the Army by His Majesty's decisive orders. ${ }^{16}$

The February 14th interview in which Konoe's advice was given to the Emperor is famous for its influence on the direction of the war. However, generally the focus of interest has been directed by historians to the part of the 
conversation in which the Emperor insisted on letting the Army and Navy fight the battle in Okinawa. It is interesting to find that on this occasion the Emperor honestly talked to Konoe about the problem he felt with the Army. This conversation reveals a delicate balance of power between the Emperor and the Army. The Imperial Constitution stipulated that "The Emperor has the supreme command of the Army and Navy,"17 and "The Emperor declares war, makes peace, and concludes treaties." However, the real power did not always come from the constitution, but from the person of the Emperor. A Japanese historian for modern Japan, Hata Ikuhiko, says that in the days when the Japanese Army and Navy were strong enough, there were some occasions when military leaders ignored what the Emperor told them, and the frustration of the Emperor accumulated. ${ }^{18}$

In discussing the relationship between the Emperor and the Army, it is necessary to talk about the role of Prince Saionji Kinmochi as a long-time advisor to the Emperor Hirohito before kido. In his young days, from 1871 to 1880 , Saionji studied European institutions and law in France. Later in his political activities he maintained a liberalist

\footnotetext{
${ }^{17}$ Article 11, Constitution of the Empire of Japan, 1889, cited in Japan: An Illustrated Encyclopedia, s.v. "Constitution" (Tokyo: Kodansha, 1993). The next article quoted here is Article 13.

${ }^{18}$ Terasaki, Dokuhakuroku, 246.
} 
and anti-military stance. He said in 1937:

A military man cannot really understand such matters as the welfare of a nation or a people. Military men advocate national unity, but their national unity is no unity at all. It just means submission to them. ${ }^{19}$

Even though he felt that the growing influence of the military was a great problem for the nation, he thought it wise not to interfere into what the Army was doing in China in 1932, when there was a question whether the Emperor should caution count Uchida for his acquiescing in the Army's aggression in North China. He said:

If the Emperor cautioned him... the Army leaders ... would blame the Emperor's advisers and me. If the Army would not heed even the words of the Emperor, it would greatly impair his prestige. So it is a very delicate matter."20

In this way, he thought that it was necessary for him to arrange the delicate relationship between the Emperor and the Army, weighing the power of the Army at the time. He died in 1940, at the age of 92, worrying about the future of Japan .

Concerning the start of the Pacific War in 1941, the Emperor recorded in his memoir that:

When my brother, Prince Takamatsu advised me not

${ }^{19}$ Harada Kumao, Saionjiko to Seikyoku, vol. 5, (Tokyo, 1950-56), 265, cited in Encyclopedia of Japan (English Version) s.v. "Saionji Kin-mochi" (Tokyo: Kodansha, 1983).

${ }^{20}$ Harada, vol.2: 420-21, cited in Encyclopedia of Japan, s.v. "Saionji Kin-mochi". 
to enter the war with the United States, I said to him that if I had not approved the war, the military would have started a coup d'état. ${ }^{21}$

This Emperor's statement reminds us of Saionji's consideration about what the Emperor could do when the military was powerful.

\section{Kido's Approach}

Kido became the Emperor's advisor after Saionji left, and like Saionji he cautiously dealt with the Army when it was strong. Even though he felt that the nation should move on to the termination of the war in the summer of 1944, he considered that before Japan decided to end the war, the nation would need to be attacked by air raids and landing of enemy troops to some degree so that the people would see the necessity of ending the war. ${ }^{22}$ It seems that Kido used the word "the people" rather euphemistically, including the Japanese Army as its important component. At that time, Kido thought that even though the war situation was not favorable for Japan, the nation was still not ready to bring the war to its end, especially since the Army did not favor it.

So between Kido and Konoe, there was a difference in their attitude toward the situation. For Kido, the Emperor

\footnotetext{
${ }^{21}$ Terasaki, Dokuhakuroku, 89.

${ }^{22}$ Hosokawa, June 26, 1944.
} 
had to wait for the good opportunity to arrive. Since kido met the Emperor almost everyday in the spring and summer of 1945, it is likely that this attitude was also taken by the Emperor. On the other hand, Konoe said that if Kido and Prime Minister Suzuki agreed to bringing the war to its termination, and the Emperor decided in the same direction the Army would follow. ${ }^{23}$ After observing the defeat of Germany, Kido began to move closer to Konoe's position.

\footnotetext{
${ }^{23}$ Memo of Tomita, Konoe's secretary to.Takagi, May 9, 1945, cited in Ososugita Seidan, 198.
} 
CHAPTER V

APPROACHING THE END OF THE WAR

In Japan, for those who thought that Japan had to end the war, the retention of the Imperial System was becoming the last thing they wished to defend. After the German surrender, in America, there were people who wanted to end the war with Japan by modifying the unconditional surrender terms, especially by giving the Japanese the assurance that they could keep the Japanese Emperor. Also in America, the completion of the atomic bomb was approaching. Those people in the American leadership who knew the secret project of producing the atomic bomb expected that the bomb would be used to end the war early. The Soviets were to enter the war three months after the German surrender according to the Yalta Agreement of February 1945, that was negotiated by President Roosevelt and Premier Stalin.

\section{American Intention Concerning the Emperor}

Konoe Fumimaro, former Prime Minister, and others who wanted an early end of the war had great concern about how the United States would treat the Japanese Emperor. Certainly, it was also the Emperor's concern. For him, the Japanese war effort was at that time no longer for the coprosperity of East Asia. He continued the war so that Japan 
could end the war on better terms, that is, to preserve the national polity. Konoe understood this circumstance, and he thought that to lead the Emperor in the direction of ending the war, it was necessary to tell the Emperor the intention of the Americans regarding the future of the Japanese Imperial system. Earlier, in February, Konoe pointed out to the Emperor that "public opinion in America and Britain, on the whole, has not yet gone so far as to demand a fundamental change in our national structure." ${ }^{1}$ Konoe probably did not know that in America, in early 1945, most of the people blamed the Japanese Emperor, and by "public opinion", he meant the opinion of some important government leaders. Konoe's use of the words "has not yet gone" is important because by these words he meant that "if the war was to continue further, they would change their attitude toward Japan." So, he advised the Emperor that an earlier ending of the war would be more advantageous. After this statement, Konoe talked about the fear of communism and Soviet expansion in the world. Considering this background, it is clear that Konoe's plan for ending the war was by direct negotiation with the United states.

After observing the defeat of Germany, Marquis Kido Koichi, the adviser to the Emperor, became increasingly concerned that Japan might share the same fate as Germany, and that Japan might not be able to safeguard the Imperial

${ }^{1}$ Butow, Japan's Decision to Surrender, 47. 
Household. On June 8 , he drafted a proposal in which he stated that:

Though it would perhaps be a good idea to initiate direct negotiations with the Anglo-Americans, who are our opponents, it would be more appropriate to have Soviet Russia, which is observing neutrality at present, act as our intermediary.

When Kido proposed negotiation with the United states and Great Britain, he said so because he perceived an indication from President Truman's statement on May 8, that the United States would only punish the militarists in Japan, and not the Emperor. ${ }^{3}$ The President's statement was as follows:

... Our blows [on the Japanese] will not cease until the Japanese military and naval forces lay down their arms in unconditional surrender. Just what does the unconditional surrender of the armed forces mean for the Japanese people? It means the end of the war. It means the termination of the influence of the military leaders who have brought Japan to the present brink of disaster. It means provision for the return of soldiers and sailors to their families, their farms, their jobs. It means not prolonging the present agony and suffering of the Japanese in the vain hope of victory. Unconditional surrender does not mean the extermination or enslavement of the Japanese people. 4

In this statement, the President did not actually refer to the Japanese Emperor. The future status of the Emperor was still a controversial subject in the American government, specifically in the state Department, even though tacit agreement was reached between the President, secretary of

${ }^{2}$ Kido, June 8, 1945.

${ }^{3}$ Ibid.

${ }^{4}$ New York Times, May 9, 1945, p6. 
War Stimson, Secretary of Navy Forrestal, and Acting Secretary of State Joseph Grew. The President's silence on retaining the Emperor implied that he recognized the difference of opinion concerning this issue in the American government and among the people. Another important feature of this statement is that President Truman emphasized that it was not the American primary purpose to harm the Japanese people, and that America would rather like the Japanese people to return to a normal, peaceful life. This idea became the base of the July 26 th Potsdam Declaration.

Kido noticed that President Truman did not mention the Emperor, but only accused the Japanese military leaders. Kido's concern was not so much about the future life of the people as about the future status of the Emperor. Even though Kido did not mention anything about the Army in his temporary choice of the soviet Union for negotiation, it is certain that the choice came from the consideration of the Army's strong request for saving its face. Also, since a certain section of the Army was listening to the American radio (that was proved at the time of the Potsdam Declaration), the Army men were aware that the negotiation with the United States would mean considerable punishment for the Army.

The Japanese leaders thought that asking the Soviets for mediation was one of the options, and seeking direct negotiation with the United States was still reserved as an 
alternative. This point is important because it was not necessarily the atomic bomb that caused the Japanese to attempt negotiation with the United States on the retention of the Emperor. In the case that the soviet route were to be closed, the Japanese had an alternative plan to directly ask the United States for negotiation, and for this move, important figures in the leadership had already had an inkling of how the United States government would respond to Japanese requests. They based their calculations on what they learned from diverse sources of information, the most important of which was the May 8 th statement by President Truman.

\section{Grew's Concern about the Soviets' Advance in East Asia}

In considering the July 26 th Potsdam Declaration, it is necessary to see the events in the American government which led to the necessity of such a declaration. In the early summer of 1945, some people in the United States government and military began to voice their opposition to the planned Soviet entry into the war against Japan. General Douglas MacArthur, Chief Commander of the United States Army in the Pacific theater, requested the soviet help throughout the war, and Soviet Premier stalin promised it to secretary of State Cordell Hull in 1943. President Franklin D. Roosevelt and stalin reached a secret agreement on the soviet entry into the Pacific War at the Yalta Conference in February 1945 
Acting Secretary of state Grew became concerned about possible Russian infringement on the American interests in East Asia in the event of the up-coming Russian invasion of Manchuria. Representing the state Department, on May 12, Grew presented three important questions relating to the Russian entry into the war and American policies in East Asia:

1. Is the Soviet entry so indispensable as to preclude political negotiation with Russia on the American interests in the East Asia?

2. Is it impossible for the U.S. to re-negotiate with the Soviets on the revision to the Yalta agreements?

3. Can Soviet occupation of Japan be avoided? Is it desirable to the U.S. interests in this area?

Grew's questions reflected the opinion of many people in the U.S. government and military that the situation of the war with Japan came to the point where the United States would no longer need Soviet assistance to defeat Japan. His second question reflected the complaints of the people that at the Yalta Conference President Roosevelt gave too many concessions to stalin in return for the soviets' aid in the war with Japan. On the whole, these questions represented considerable concerns of the American leadership regarding the Soviet entry into the Pacific War scheduled three months after the German surrender according to the Yalta Agreement.

Stimson answered these questions:

${ }^{5}$ Memo, Acting Secretary of state Grew for secretary Stimson, May 12, 1945, in The Entry of the soviet Union inte the War Against Japan: Military Plans, 1941-1945 (Washington D.C., 1955), hereafter cited Entry of Soviet Union. 
... Russian entry into the war against Japan will be decided by the Russians on their own military and political basis with little regard to any political action taken by the United States.

stimson fully understood that the ulterior objective of the Soviets' aid in the Pacific War was for them to retrieve and acquire from Japan as much territory as they could in East Asia, especially to reverse the victory Japan won at the Treaty of Portsmouth in 1905. So he indicated the impossibility of the political renegotiation of the Yalta Agreement. As for the possibility of the soviet occupation of Japan, Stimson cited American "experiences with the Russians in the occupation of Germany" and pointed "to the wisdom of exclusive occupation" by American forces.? Relating to this matter, stimson said in this letter to Grew that American military strength in this area was enough to defeat Japan alone. Stimson probably meant that it would be advisable for the United States at this stage of the war to concentrate its forces on securing the earlier defeat of Japan before anyone else would try to reach Japan. ${ }^{8}$

In those days, stimson was considerably concerned about the development of the atomic bomb. On May 13, 1945, the day after stimson got Grew's memo, in his diary he related Grew's questions to the program of developing the atomic

\section{${ }^{6}$ Letter, Secretary stimson to Acting Secretary Grew,} May 21, 1945, cited in Entry of Soviet Union, 70.

Ibid., 71 .

${ }^{8}$ Ibid. 
bomb.

These are very vital questions and I am very glad that the state Department has brought them up and given us a chance to be heard on them. The questions cut very deep and in my opinion are powerfully connected with our success with $S-1$ [the atomic bomb].

In this diary entry, stimson revealed a strong connection between the Soviet problems and the expected American possession of the atomic bomb.

\section{Discussion on Warning Announcement to the Japanese}

On May 29, Acting Secretary of state Grew called a meeting of state, War and Navy secretaries and their aides to discuss a planned warning announcement to the Japanese. It was Grew's idea that by giving the Japanese an assurance that the Japanese could keep the Emperor, the United states would bring the earlier termination of the war.

This idea was strongly supported by secretary of Navy Forrestal. After the Battle of Iwojima, he investigated the result of the battle on the island, and felt the necessity of stopping further bloodshed. Under his auspices, Captain Zacharias was to begin a series of propaganda broadcast toward Japan in the middle of May 1945, for urging the Japanese to end the conflict. ${ }^{10}$

Stimson recorded a significant diary entry about the

${ }^{9}$ Stimson Diaries, May 13, 1945.

${ }^{10}$ Captain Ellis M. Zacharias, USN, Secret Missions: The Story of an Intelligence officer (New York: G.P. Putnam's Sons, 1946), 330 . 
meeting :

It was an awkward meeting because there were people present in the presence of whom I could not discuss the real feature which would govern the whole situation, namely $s-1$ [the atomic bomb]. ... I told him that I was inclined to agree with giving the Japanese a modification of the unconditional surrender formula and some hope to induce them to practically make an unconditional surrender without the use of those words. I told him that I thought the timing was wrong and that this was not the time to do it. ${ }^{11}$

The matter of the atomic bomb was top secret, and knowledge of it limited to only a few people. From this statement, it is certain that in stimson's mind the atomic bomb and the issue of giving the Japanese a modified surrender formula were related. When stimson said that "this was not the time to do it," he was thinking about the relation between the timing of the perfection of the atomic bomb and the timing of the modification of the surrender terms.

\section{July 2nd Stimson's Memo to the President}

On July 2, 1945, Stimson gave to President Truman a memo which incorporated basic ideas for the Potsdam Declaration of July 26. In the letter to Truman that accompanied the memo, stimson mentioned that the ideas for a warning to Japan were the result of the discussion between Stimson, Grew, and Forrestal. Stimson stated that this warning to Japan would be revised when the efficacy of a new weapon was proved. So here, stimson thought a combination

${ }^{11}$ Stimson Diaries, May 29, 1945. 
of a warning to Japan in the form of the Potsdam

Declaration, and the power of a new weapon would bring Japan to its surrender.

The July 2nd draft of the proclamation which was to be eventually delivered to the Japanese included the retention of the Emperor:

The occupying forces of the Allies shall be withdrawn from Japan as soon as our objectives are accomplished and there has been established beyond doubt a peacefully inclined, responsible government of a character representative of the Japanese people. This may include a constitutional monarchy under the present dynasty if it be shown to the complete satisfaction of the world that such a government will never again aspire to aggression. ${ }^{12}$

The assurance of the retention of the Imperial system reflected Grew's strong opinion that this clause was vital for the acceptance of the proclamation by the Japanese.

\section{Deletion of the Emperor Clause}

The part of the proclamation that included the assurance of retaining the Japanese Imperial System was deleted by Secretary of State James Byrnes after he consulted with former secretary of state cordell Hull on July 16. Hull said in his letter to Byrnes:

... The proponents believe that this step [modifying the unconditional surrender terms] might shorten the war and save allied lives. The theory is that somehow the influences and persons

\footnotetext{
${ }^{12}$ Foreign Relations of the United states, Diplomatic Papers: The conference of Berlin (The Potsdam conference) 1945 volume I (Washington: United States Government Printing Office, 1960), 894; hereafter cited FRUS.
} 
who listen to the Emperor and his religion would fight and resist less hard and so save allied lives and shorten the war, et cetera, etcetera. Undoubtedly, if this undertaking should prove successful it would be still more appealing. The other side is that no person knows how the proposal would work out. The militarists would try hard to interfere. Also should it fail the Japs would be encouraged while terrible political repercussions would follow in the U.S. Would it be well first to await the climax of allied bombing and Russia's entry into the war? ${ }^{13}$

Hull did not oppose giving the Japanese the assurance of retaining their Emperor. He did not believe that this assurance would immediately make the Japanese lay down their arms. Certainly, the inclusion of the Emperor clause would cause more vehement discussion in the Japanese government and military circles than otherwise. What if "the climax of allied bombing" occurred while the Japanese were trying to reach their consensus. It would enrage not only militarists, but also make the peace-minded Japanese change their opinion about America. Hull might have heard that a new weapon would have enough power to destroy a city. In his memoir, Hull said that he had not been told by President Roosevelt about the bomb, but "Occasionally someone gave me a veiled hint."14 Hull considered the possible Japanese response to the warning announcement and the atomic bombing more politically and realistically than stimson did. This is also a question of how much and why the United Stated

\footnotetext{
${ }^{13}$ Ibid., volume II, 1267.

${ }^{14}$ Cordell Hull, The Memoirs of Cordell Hull, 1, 110.
} 
needed to use the atomic bomb. If the Emperor clause had been included in the warning announcement, and the Japanese had been taking time to reach a decision for response, the time for the soviet entry into the war came anyway. Was it advantageous from the American point of view? To Secretary of State Byrnes, the answer was "no", because he did not want the Soviets' ending the Japanese war.

Stimson thought that if the Japanese were to persist after the warning announcement, the power of a new weapon would be imposed on Japan. ${ }^{15}$ As to Stimson's proposition, if the Japanese had accepted the warning announcement with the assurance of the retention of the Imperial system, what would have happened to the United States plan to use the atomic bomb? Stimson said that the assurance of the dynasty "would make or mar their acceptance." 16 This statement indicates that if the Japanese were to accept the warning announcement with the Emperor clause, and the war were to come to its end without American use of the atomic bomb, stimson thought that it was all right. Then, how about Stimson's previous idea that the American interests in East Asia vis-à-vis the Soviet Union was very much related to the efficacy of the atomic bomb. ${ }^{17}$ Considering his conditions

\footnotetext{
${ }^{15} \mathrm{~A}$ memo from stimson to the President, in FRUS. The Conference of Berlin volume II, 1266.

${ }^{16}$ Stimson Diaries, July 24, 1945.

${ }^{17}$ Stimson Diaries, May 13, July 15, July 17, 1945.
} 
might help to solve this question. According to his diaries, since he had such a serious health problem, his medical doctors regularly checked his health condition. He was surrounded by men of strong character, so he was likely to be influenced by what they said and what they did. Grew and Forrestal urged the inclusion of the Emperor clause in the warning announcement, and Byrnes decided for the deletion of the clause.

\section{The Japanese and the Potsdam Declaration}

Japanese Foreign Ministry officials received the broadcast of the Potsdam Declaration as something that would bring the war to its termination. They had heard Zacharias' broadcast time and time again, so they soon interpreted it to mean that the United states was not opposed to retaining the Japanese Emperor. This became the position of Foreign Minister Togo. However, at that time, Togo believed that the Japanese had to wait for the soviet reply to the Japanese request of Soviet mediation in the war, and he stated this opinion in the cabinet meeting.

On July 27, Tanemura recorded in the staff office diary two interpretations of the fact that the Soviet Union did not join the July 26th Potsdam Declaration:

1. The Soviets did not join it because they would need Japan as a friendly nation to them in the worsening international situation.

2 . The Soviets would soon enter the war against Japan, and to keep it secret they did not join the 
proclamation. ${ }^{18}$

Colonel Tanemura sako wrote that since it was human nature to take the easy way, the officers at the staff Office tended to think that stalin was wise enough not to make Japan his enemy. Tanemura indicates that the Japanese were considerably concerned about the intention of the soviet Union.

On this day, Tanemura participated in the meeting of the secretaries for the supreme War Council. They decided that they would just keep silent concerning the Potsdam Declaration. 19 "Keep silent" meant no answer to the Allies. Why did they decide to keep silent? There were several reasons: First, the opinions were divided among the Japanese over the interpretation of the Declaration, the main point of the controversy was whether the Allies intended to allow the Japanese to keep the Emperor. Second, the soviet position was not clear, and Soviet officials promised the Ambassador to Moscow, Sato Naotake, that the Soviet government would answer to the Japanese request of mediation after stalin and Molotov returned from Potsdam, and the Japanese government wanted to hear the Soviets' answer. Third, the Japanese feared that an open refusal would mean further American air raids and an invasion of the Japanese homeland as the warning announcement stipulated. Fourth,

\footnotetext{
${ }^{18}$ Tanemura, July 27, 1945.

${ }^{19}$ Ibid.
} 
any indication of willingness to accept the Declaration that proclaimed punishing Japanese militarists seemed to invite the danger that young Army officers might move for a coup d'état. What is remarkable is that the Japanese government did not officially announce that the Japanese would oppose the Potsdam Declaration, though the United States government interpreted Prime Minister Suzuki's word "mokusatsu", meaning "ignore", as the Japanese refusal to the Declaration. This interpretation became the American excuse to use the atomic bomb on Japan. However, the order to drop the bomb had already been issued from Potsdam on July 25, the day before the Potsdam Declaration, and as we saw before, the key figures in the American leadership had already expected that the Japanese would not immediately accept it.

\section{The Army Staff office}

On July 30, at the Army Staff Office, in the conversation among the officers, Tanemura felt that they lost the morale to fight with Americans, and they expected the Soviet diplomatic effort to solve the issue for Japan. Tanemura got infuriated at their attitudes as army officers, and shouted, "Isn't your duty to find the way to winning the war? Don't depend on others." He wrote that he shuddered with a complaint that "The Army headquarters with such demoralized officers cannot lead the people to fighting on 
the homeland."20 The next day, Tanemura was ordered to work at the staff office in Korea, and the diary ended on this day. ${ }^{21}$ The note to the diary says that at the end of the war Tanemura became a prisoner to the Soviet Army. ${ }^{22}$

\section{The Atomic Bombing and the Soviet Entry into the War}

The United States dropped the atomic bomb on Hiroshima on August 6. After receiving the report of the news on August 7, Foreign Minister Togo met the Emperor and advised him to act to terminate the war. The Emperor said:

...We could no longer continue the struggle, now that a weapon of this devastating power was used against us, we should not let slip the opportunity by engaging in attempts to gain more favorable conditions.

However, no immediate meeting of the senior statesmen and military leaders for the occasion of emergency was held. It was on the morning of August 9, when the Soviet Union began to attack the Japanese forces in Manchuria, that the Emperor told Kido to consult with Prime Minister Suzuki and to take measures to bring the war to its end. ${ }^{24}$ The question of which event gave more impact to the Japanese in their decision to end the war has been discussed. On August 12,

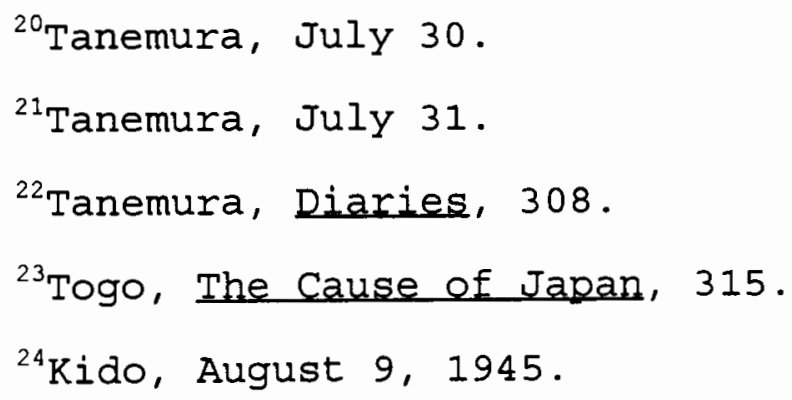


1945, Navy Minister Yonai said to Takagi:

Though I do not fear either the Atomic bombing or the Soviet entry into the war, these are the help of heaven to us, because now we can end the war without incurring domestic conflicts and disturbances. ${ }^{25}$

When Konoe heard the news of the soviet entry into the war, he said "This is the help of heaven." Yonai and Konoe thought that if the war continued, the internal disturbances were sure to develop. Even though on July 12, Konoe had received a mission from the Emperor to go to Moscow as a plenipotentiary to ask for Soviet mediation, in the first place, it was not his original wish, for he held strong anti-Soviet sentiment. Considering Japanese fear and anxiety about the soviet entry into the war, it is certain that the Soviet entry into the war gave a considerable impact to the Japanese leaders. In June, Togo said that when the Soviets invaded Manchuria to enter the war with Japan, it was the time of the end of the Japanese Empire. ${ }^{26}$ The major obstacles for the Japanese effort to bring the war to its end were removed when the Soviet attack on the Japanese forces opened the way for direct negotiation with the United states. It is important to note that this alternative had already been considered much earlier in various sections in the Japanese government. The elusive wish of the Japanese Army and others to ask the Soviet

\footnotetext{
${ }^{25}$ Yonai, Memoir, 153.

${ }^{26}$ Togo, The cause of Japan, 312 .
} 
mediation of the war finally crashed.

\section{One Condition or Four Conditions}

On August 9, in the Cabinet meeting and the Supreme war Council meeting for discussing the acceptance of the Potsdam Declaration, Foreign Minister Togo insisted on just asking the United States to let the Japanese keep the national polity, in other words, keep the Imperial System. The Army leaders, Anami and Umezu, insisted on adding three other terms: The Japanese disarm themselves; the Japanese try the Japanese war criminals, and that there would be no occupation of Japan by foreign Powers. The addition of these terms clearly contradicted the terms in the Potsdam Declaration, which stipulated that the Japanese militarists would be punished. So the Army leaders actually wanted to protect their organization, and others acquiesced. However, the opposition arose from outside these conferences. Prince Takamatsu, the Emperor's younger son, telephoned to Kido "fearing that the Allied powers might take our conditional acceptance as a refusal." 27 Then, Shigemitsu Mamoru, Foreign Minister until April, 1945, visited Kido's office to tell him that "a rupture would be inevitable if we should lay down the four conditions." After Kido obtained the Emperor's approval, the Emperor told Prime Minister Suzuki to convene an Imperial Conference. From 11:50PM to 2:20AM, 
the Conference was held in the Emperor's presence. There, the Emperor presented his judgement to accept the Potsdam Declaration on the condition that the preservation of the Imperial dynasty and the right of sovereignty of the Emperor be acknowledged. ${ }^{28}$

The Emperor, subject to the supreme Commander

On August 12, the Japanese government received the American reply that was written by secretary of state James Byrnes. Paragraph 2, and paragraph 5, then became controversial within the government.

From the moment of surrender, the authority of the Emperor and the Japanese Government to rule the state shall be subject to the supreme Commander of the Allied powers, who will take such steps as he deems proper to effectuate the surrender terms.

The ultimate form of government of Japan shall, in accordance with the Potsdam Declaration, be established by the freely expressed will of the Japanese people. ${ }^{29}$

The Army leaders again opposed these terms interpreting the term "subject" as "enslaved". In the Army headquarters, these leaders were actually hearing vehement protests of young officers who opposed the Potsdam Declaration in the first place. These opponents asserted that the second paragraph denied the national polity of Japan. The democratic idea in this paragraph was quite foreign to the Japanese in those days, especially to the Army men, because

\footnotetext{
${ }^{28}$ Ibid.

${ }^{29}$ Togo, The Cause of Japan, 324 .
} 
of the kind of education they received.

Kido heard Prime Minister Suzuki begin to take a position that these two paragraphs would not guarantee the future status of the Emperor. Suzuki had a tendency since he took his office to cater to the demand of the Army men. He later claimed that by a posture of compromising with the Army, he tried to avoid its attempt of resorting to a coup d'état. Also, since he was a survivor in the attempted assassination in the February 26 th incident in 1936, he was considerably carefull in dealing with the Army men. In persuading Prime Minister Suzuki, Kido told Suzuki that:

if we do not take an immediate action now to terminate the war, twenty million people will die. If we take a necessary action now, only several people will probably die; me, you, and a few others. ${ }^{30}$

Kido and Suzuki decided to use the Emperor's decision to accept the American terms. On the night of August 14-15, Kido was searched in the Imperial Palace by the Army rebels who rose to attempt a coup d'etat, and Suzuki's official residence and private home were assaulted and burned by other rebels.

On August 14, the Emperor convened the Imperial Conference and he announced his decision to accept the American terms for the Japanese surrender on the ground that he was convinced of the United States' intention to keep the

${ }^{30}$ Hando Kazutoshi, Nihon no Ichiban Nagai Hi. [Japan's Longest Day] (revised edition) (Tokyo: Bungeishunjusha, 1995), 43; Shoda, History of Statesmen, 382. 
Japanese Imperial System and he had confidence that the Japanese people would support the Emperor. On that evening, the Foreign Ministry officials sent the message of acceptance of the Potsdam Declaration, and the next day, on August 15, the Emperor announced to the Japanese people by a radio broadcast that Japan would end the war. 


\section{CONCLUSION}

In the summer of 1945, the Japanese no longer possessed strength to engage in a battle on the home land. The government and the military claimed that the Japanese would engage in a 100 million suicides war, if the Americans were to land on the Japanese homeland. However, this was propaganda without any substance. Many Japanese people were hungry and busy seeking food. The morale of the people was rapidly deteriorating mainly because of the devastating air raids. Though the Army claimed that it had two million troops in the home islands, there were only about 700,000 rifles, and many actually would be requested to fight with bamboo spears. The Emperor mentioned that the war started because of oil, and the nation had to end the war because of the scarcity of oil. Though he simplified the situation, he pointed that Japan could not continue the war because of the scacity of materials. The loss of Japanese control of the sea and air increased American blockade of the Japanese homeland and contributed to the further scarcity of materials.

The May 8th German surrender and the Japanese defeat at Okinawa in June showed the Japanese what it would be like if the United States armed forces landed on the Japanese mainland. Contrary to its previous pledge, many now believed that the Japanese military was unable to defend the 
island and the people. Rather, even after the defeat in Okinawa became clear in early May, the Army kept fighting until June 23, thus becoming responsible for approximately 150,000 civilian deaths. The Army lost its credibility. In the homeland of Japan, the army had already revealed its inability to defend the people against the American air raids, though they did not reveal their weakness so that they would not lose face. War Minister Anami's attempt to resign from his post because he was unable to defend the Imperial Palace from air raid signified the seriousness of the problem of air raids in general. The Emperor discovered that the previous Army Chief's report on defense conditions was false after sending his own military attendants to investigate the same areas. The investigation also revealed the dangerously low level of military strength of Japan at the time.

The May 8 th German defeat increased Japanese concern about possible Soviet entry into the war against Japan. The Army Chief's report on defense conditions in Manchuria stunned the Emperor. Men and arms had been drained from Manchuria to the Pacific, resulting from the severity of the Pacific War and the Japanese reliance on the Neutrality Treaty with the Soviet Union. If the Soviets were to invade Manchuria, it was feared by the Japanese that it would turn out to be a corridor for the Soviets' southern advance toward Japan. Diplomatic negotiation with the Soviet Union 
to ask for continued Soviet neutrality and Soviet mediation in the Pacific War became an urgent task for the Japanese government. The Japanese government decided to ask the Soviets to abide by the treaty and mediate in the Pacific War. That was the major desire of the Army leaders. The Army and Navy leadership came to a point where many of them wanted to end the war by the time of the Japanese defeat in Okinawa. The Army Ieaders thought that in that way they could end the war without losing face. Others in the Japanese leadership acquiesced, thinking it to be the way to bring the Army to the road toward ending the war, though many of them had the alternative plan of asking for direct negotiation with the United States if the Soviet route was closed.

The retention of the Japanese Emperor was a focal point for the United States and Japan in bringing the war to the end. The Japanese government proclaimed that the Japanese would fight to the end to achieve this objective, though they no longer had substantial will and power in the nation. Through these propaganda actions, the Japanese expected a political gain. In the early summer of 1945, some important figures in the American government began to think that it was advisable to end the war by allowing the Japanese to retain the Emperor. This matter finally materialized between the United States government and Japanese government. In the meantime, the United States dropped the 
atomic bomb on Hiroshima and the Soviet Union invaded Manchuria.

There are diverse opinions about how the Pacific War came to its end. To say that "The United States' dropping the atomic bomb ended the war," is too simplistic. This statement overlooks many other factors, especially the human factors, that contributed to the termination of the war. 


\section{BIBLIOGRAPHY}

\section{(1) English Language Primary Sources}

Arnold, Henry. Global Mission. Blue Ridge Summit, PA: Tab Books, 1949 .

Hull, Cordell. The Memoirs of Cordell Hull. New York: MacMillan, 1948.

Stimson, Henry L. Diaries. New Haven, Connecticut: Sterling Memorial Library, Yale University. [Microfilm]

Zacharias, Captain, USN, Ellis M. Secret Missions: The Story of an Intelligence officer. New York: G.P. Putnam's Sons, 1946 .

President Harry Truman's the May 8 th statement, The New York Times, May 9, 1945: p6.

Foreign Relations of the United States, Diplomatic Papers: The conference of Berlin (The Potsdam Conference) 1945 volume I, volume II. Washington: United States Government Printing office, 1960.

Washington: U.S. Government Printing Office.

\section{(2) English Language Secondary Sources}

Bix, Herbert P. "Japan's Delayed Surrender:

A Reinterpretation," Diplomatic History, 19:2, spring 1995 .

"The Showa Emperor's "Monologue" and the Problem of War Responsibility," Journal of Japanese Studies, $18: 2$, 1992 .

Blackett, P.M.S. Military and Political Consequences of Atomic Energy [The title of the American publication: Eear, War, and the Bomb] New York and Toronto:

Whittlesey House. McGraw-Hill Book Company, Inc., 1948.

Butow, Robert. Japan's Decision to Surrender. Stanford, California: Stanford University Press, 1954. 
Coox, Alvin D. Nomonhan: Japan Against Russia, 1939.

Stanford, California: Stanford University Press, 1985.

Dower, John W. War Without Mercy: Race and Power in the Pacific War. New York: Pantheon Books, 1986.

Havens, Thomas R. H. Valley of Darkness: The Japanese People and World War II. New York: W.W. Norton \& Company Inc., 1978 .

Iriye Akira. Power and Culture: The Japanese-American War, 1941-1945. Cambridge, Massachusetts \& London, England: Harvard University Press, 1981.

The Entry of the Soviet Union into the War Against Japan: Military Plans, 1241-1945. Washington D.C.: Department of Defense, 1955.

\section{(3) Japanese Primary Sources}

Higashikuni Naruhiko. Higashikuni Nikki [Higashikuni Diaries]. Tokyo: Tokuma-shoten, 1968.

Hosokawa Morisada. Hosokawa Nikki [Hosokawa Diaries]. Tokyo:Chuko-bunko, 1979.

Kido Koichi. The Diary of Marquis Kido, 1931-45. Frederick, Maryland: University Publications of America, 1984. The diary, consisting of many handwritten volumes, was seized by the International Prosecution Section of the International Military Tribunal for the Far East in 1946. This book is a collection of all the excerpts translated into English that were used or proposed to be used as evidence during the trial.

Matsutani Makoto, Daitoa-senso Shuketsu no shinso [The True Story of Ending the Japanese War]. Tokyo: Fuyo-shobo, 1984.

Sanematsu Jo, ed. Yonai Mitsumasa Oboegaki, [Yonai Mitsumasa Memoir]. Tokyo: Kojinsha, 1988.

Takagi Sokichi. Shusen Oboegaki [Recollections of the Termination of the War]. Tokyo: Kobundo, 1948.

Takagi Sokichi. Takagi Kaigun Shosho oboegaki [Rear Admiral Takagi's Memoir]. Tokyo: Mainichi-shinbunsha, 1979.

Takagi Sokichi. Shusen Oboegaki [Recollections of the 
Termination of the War]. Tokyo: Kobundo, 1948.

Takagi Sokichi. Takagi Kaigun Shosho Oboegaki [Rear Admiral Takagi's Memoir]. Tokyo: Mainichi-shinbunsha, 1979.

Tanemura Sako. Daihonei Kimitsu-nisshi [Secret Diary of General Staff Office]. Tokyo: Fuyo-shobo, 1985.

Terasaki Hidenari. Showa Tenno Dokuhakuroku [Showa Emperor's Monologue]. Tokyo: Bunshun-bunko, 1995.

Togo Shigenori. The Cause of Japan. New York: Simon and Schuster, 1956, translated and edited from Jidai no Ichimen (Tokyo, 1952) by Togo Fumihiko and Ben Bruce Blakeney.

(4) Japanese Secondary Sources

Fujiwara Akira, Yoshida Yutaka, Ito Satoru, Kunugi Toshihiro. Tenne no Showashi [Emperor's History of Showa Period]. Tokyo: Shin-nihon-shuppansha, 1988.

Fujiwara Akira, Awaya Kentaro, Yoshida Yutaka, Yamada Akira. Tettei-kenshe Showa Tenno Dokuhakuroku [Ful] investigation of the monologue of Showa Emperor]. Tokyo: Otsuki-shoten, 1991.

Fujiwara Akira, Awaya Kentaro, Yoshida Yutaka. Showa 20 Nen, 1945 [Showa 20th Year]. Tokyo: Shogakukan, 1995.

Hando Kazutoshi. Nihon no Ichiban Nagai Hi [The Longest Day of Japan] (revised edition). Tokyo: Bungeishunjusha, 1995 .

Kojima Jo. Tenno [Emperor]. Tokyo: Bunshun-bunko, 1981.

Nishijima Ariatsu. Genbaku wa Naze Otosaretaka [Why was the Atomic Bomb Dropped?]. Tokyo: Aoki-shoten, 1985.

Ohta Masahide. Okinawa-sen towa Nanika [What Does the Battle of Okinawa Mean?]. Tokyo: Kame-shobo, 1985.

Saotome Katsumoto. Tokyo Daikushu [Tokyo Great Air Raid] . Tokyo: Iwanami-shinsho, 1971.

Shoda Tatsuo. Jushintachi no Showa-shi [Showa History of Senior Statesmen]. Tokyo: Bunshun-bunko, 1984.

Showa-shi Kenkyu-kai. Showa-shi Jiten [Dictionary of Showa History]. Tokyo: Kodansha, 1984. 
Tanaka Nobumasa. Dokyumento Showa Tenno (5) Haisen [Documented History of Showa Emperor]. Tokyo: Ryokufushuppan, 1988 .

Taniguchi Katsuhisa. Noro-kochi Dokudan-tettai: Nomonhan no Hiroku [Retreat without Order from Noro Highland:

Secret Records about Nomonhan Incident]. Tokyo:Oshisha, 1986.

Yamada Akira and Koketsu Atsushi. Ososugita Sejdan: Showa Tenno no Senso-shido to Senso-sekinin [Emperor's Delayed Decision: Emperor Showa's Direction of the War and His Responsibility]. Tokyo: Showa-shuppan, 1991.

Yoshida Yutaka. Showa Tenno no Shusenshi [Showa Emperor's History of ending the War]. Tokyo: Iwanami-shinsho, 1992.

Daihonei Rikugun-bu [General staff office, Army

Department]. Tokyo: Asagumo-shuppansha, 1975.

Encyclopedia of Japan [English edition]. Tokyo: Kodansha, 1983.

Japan: An Illustrated Encyclopedia [English edition]. Tokyo: Kodansha, 1993. 